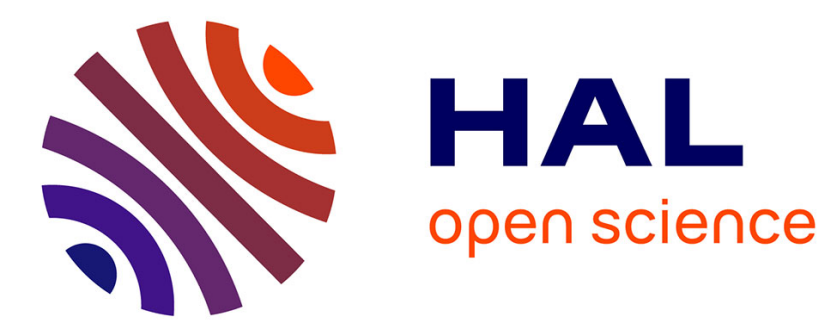

\title{
Vestibular Schwann cells are a distinct subpopulation of peripheral glia with specific sensitivity to growth factors and extracellular matrix components
}

Sylvain Bartolami, Christelle Augé, Cécile Travo, Stéphanie Ventéo, Marlies Knipper, Alain Sans

\section{To cite this version:}

Sylvain Bartolami, Christelle Augé, Cécile Travo, Stéphanie Ventéo, Marlies Knipper, et al.. Vestibular Schwann cells are a distinct subpopulation of peripheral glia with specific sensitivity to growth factors and extracellular matrix components. Journal of Neurobiology, 2003, 57 (3), pp.270-290. 10.1002/neu.10302 . hal-02156325

\section{HAL Id: hal-02156325 \\ https://hal.science/hal-02156325}

Submitted on 18 Jun 2019

HAL is a multi-disciplinary open access archive for the deposit and dissemination of scientific research documents, whether they are published or not. The documents may come from teaching and research institutions in France or abroad, or from public or private research centers.
L'archive ouverte pluridisciplinaire HAL, est destinée au dépôt et à la diffusion de documents scientifiques de niveau recherche, publiés ou non, émanant des établissements d'enseignement et de recherche français ou étrangers, des laboratoires publics ou privés. 


\title{
Vestibular Schwann Cells Are a Distinct Subpopulation of Peripheral Glia with Specific Sensitivity to Growth Factors and Extracellular Matrix Components
}

\author{
Sylvain Bartolami, ${ }^{1}$ Christelle Augé,, ${ }^{1}$ Cécile Travo, ${ }^{1}$ Stéphanie Ventéo, ${ }^{1}$ \\ Marlies Knipper, ${ }^{2}$ Alain Sans ${ }^{1}$ \\ ${ }^{1}$ INSERM U.583, Université Montpellier II, Place Eugène Bataillon, 34090 Montpellier, France \\ ${ }^{2}$ Laboratory of Molecular Neurobiology, Hearing Research Center of Tübingen, THRC, Elfriede \\ Aulhornstr. 5, 72076 Tübingen, Germany
}

Received 20 February 2003; accepted 11 July 2003

\begin{abstract}
Vestibular nerve Schwann cells are predisposed to develop schwannoma. While knowledge concerning this condition has greatly improved, little is known about properties of normal vestibular Schwann cells. In an attempt to understand this predisposition, we evaluated cell density regulation and proliferative features of these cells taken from 6-day-old rats. Data were compared to those obtained with sciatic Schwann cells. In both vestibular and sciatic 7-day-old cultures, Schwann cells appear as bipolar or flattened cells. However, sciatic and vestibular cells greatly differ in other aspects: on poly-L-lysine coating, sciatic cells specifically synthesize myelin basic protein, while expression of $\mathbf{P 0}$ mRNAs is restricted to some vestibular cells. Laminin increases sciatic cell density but not that of vestibular cells. Fibronectin selectively enhances the proliferation of vestibular Schwann cells and lacks an effect on sciatic
\end{abstract}

ones. Comparison of cell density changes between sciatic and vestibular cells shows that they are sensitive to two different sets of growth factors. Progesterone and FGF-2 combined with forskolin selectively enhance the cell density of sciatic glia, while IGF-1 and GDNF specifically increase vestibular cell density. Furthermore, BrdU incorporation assays indicate that GDNF is also a mitogen for vestibular cells. Altogether, vestibular Schwann cells display phenotypic features and responsiveness to exogenous signals that are significantly different from sciatic Schwann cells, suggesting that vestibular glia form a subpopulation of Schwann cells. () 2003 Wiley Periodicals, Inc. J Neurobiol 57: 270-290, 2003

Keywords: vestibular Schwann cells; proliferation; phenotype; growth factors; extracellular matrix proteins; NF2/type 2 neurofibromatosis protein; inner ear

\section{INTRODUCTION}

Glia of the peripheral nervous system originate from neural crest stem cells and constitute a wide population of Schwann cells, subdivided into several fami-

Correspondence to: S. Bartolami (sly@univ_montp2.fr). (C) 2003 Wiley Periodicals, Inc.

DOI 10.1002/neu.10302 lies: the terminal Schwann cells of the neuromuscular junction, the enteric glia, the ganglionic satellite cells, and the Schwann cells surrounding nerve fibers. Among these various cells, few of them are able to elaborate myelin. They are the myelinating Schwann cells, mostly found in nerves and exceptionally in ganglion, such as the vestibular ganglion. The other Schwann cells share features of the somewhat less differentiated nonmyelinating phenotype (Mirsky and Jessen, 1996; Zorick and Lemke, 1996). Both myeli- 
nating and nonmyelinating cells are distinguishable by the expression of specific markers. For instance, myelinating cells synthesize the myelin proteins: $\mathrm{P} 0$, myelin basic protein (MBP), myelin associated glycoprotein, peripheral myelin protein 22 , and the transcription factor Krox 20 (Jessen and Mirsky, 1991; Lemke, 1993; Topilko et al., 1997). As for nonmyelinating cells, they bear the p75 low affinity neurotrophin receptor and the adhesion molecule NCAM on their membrane and contain the glial fibrillary acidic protein (GFAP) and the transcription factors Krox 24 and Pax 3 (Jessen et al., 1987, 1990; Kioussi et al., 1995; Topilko et al., 1997). In addition, myelinating and nonmyelinating Schwann cells are distinguished in more subtle fashion by reduced expression of S100 protein in nonmyelinating cells with respect to the myelinating ones (Mata et al., 1990).

Whatever their subtypes, Schwann cells rely on close interactions with neurons, from early glial commitment (Jessen et al., 1994; Shah et al., 1994) to differentiation into myelinating or nonmyelinating cells (Jessen et al., 1987, 1990; Chan et al., 2001). Reciprocally, Schwann cells are important for neurons because they support their survival, axonal maturation, modulation of synaptic transmission, and repair (Son et al., 1996; Trachtenberg and Thompson, 1996; Yin et al., 1998; Jessen and Mirsky, 1999; Martini, 2001). Neuroglial communication is based on complex signaling that involves many intercellular messengers, including growth factors and extracellular matrix components (Baron-Van Evercooren et al., 1986; Marchionni et al., 1993; Lobsiger et al., 2000; Chan et al., 2001; Podratz et al., 2001).

The loss of Schwann cell/neuron contacts triggers tremendous alterations in Schwann cells, leading to dedifferentiation towards immature stages. Hence, myelin genes are down-regulated whereas markers of the nonmyelinating phenotype are up-regulated (Lemke and Chao, 1988; Jessen et al., 1990). Dedifferentiation is necessary for the Schwann cells to re-enter the cell cycle because their proliferation depends on myelin break down (Fernandez-Valle et al., 1995). Both glial dedifferentiation and proliferation are beneficial for post-traumatic axonal regeneration (Fu and Gordon, 1997). Conversely, deregulation of Schwann cell mitotic rate and/or survival leads to the occurrence of benign tumors such as schwannomas. In this condition, tumoral Schwann cells cause, besides dysfunction of axonal conduction, fiber degeneration and neuronal death (Sans et al., 1996). Although schwannoma can arise from many nerves, the vestibular nerve is a particular locus harboring that lesion. Vestibular innervation displays high predisposition and poor prognostic to schwannomas (Evans et al., 2000). Despite the above cited facts and the increasing knowledge about the NF2 gene and protein defects underlying the pathophysiology of schwannoma (Rouleau et al., 1993; Trofatter et al., 1993; Evans et al., 2000; Sherman and Gutmann, 2001), little is known about normal Schwann cells of the vestibular nerve. Their phenotype remains to be clearly established, together with mechanisms involved in their development and differentiation. Vestibular Schwann cells deserve more interest because they also form an unusual neuron/glia couple with respect to lineage. While most Schwann cells are associated with neurons arising from neural crest or neural tube (i.e., neurectodermal structures), vestibular Schwann cells principally interact with neurons originated from an ectodermal structure: the otic placode (D'Amico-Martel and Noden, 1983).

These two peculiar features of vestibular Schwann cells prompted us to undertake a specific characterization of the regulation of their density and proliferation in controlled conditions. In addition, differentiation of these cells was assessed by studying the expression of proteins related to the schwannian lineages. In order to identify properties distinguishing vestibular Schwann cells, their in vitro behavior was compared to that of the well characterized sciatic glia. Obtained results should shed light on the understanding of developmental regulation of vestibular glia and schwannomatosis. Our experiments demonstrate that vestibular and sciatic cells express different markers in vitro and display differential sensitivity to growth factors and extracellular matrix components. In view of the current data and the developmental and pathological knowledge concerning the vestibular nerve, we suggest that the vestibular glia should be considered as a subpopulation of Schwann cells.

\section{METHODS}

\section{Culture}

Unless otherwise specified, all reagents were obtained from Sigma (St. Louis, MO). Primary Schwann cell cultures were developed in defined medium, and cells were isolated from vestibular and sciatic nerves dissected from 6-day-old Wistar rats, according to the university animal care regulations. Nerves were dissected out in L15 medium, and perineuriums were removed. Sciatic tissues were further lacerated. Concerning vestibular nerves, only their distal segments (between the Scarpa ganglion and the sensory epithelia) were used in order to avoid meningeal and central glial cell contaminations. Then, nerves were incubated in a mixture of dispase II (Roche, Basel, Switzerland) collagenase and DNAse at $1 \mathrm{mg} / \mathrm{mL}$ each in L15 medium (Gibco 
Invitrogen, Paisley, UK), for $45 \mathrm{~min}$ at room temperature. This incubation was terminated by three washes with $\mathrm{Ca}^{2+}$ $\mathrm{Mg}^{2+}$ free Tyrode's buffer. Tissue samples were collected in defined culture medium (DMEM/Ham's F12 50\% each $\mathrm{vol} / \mathrm{vol}$, containing $5 \mathrm{~g} / \mathrm{L}$ glucose, $2 \mathrm{~m} M$ glutamine, 10,000 $\mathrm{U} / \mathrm{mL}$ penicillin, and $10 \mathrm{mg} / \mathrm{mL}$ streptomycin) and mechanically dissociated. The dissociation yield was determined by counting with a Malassez device, and dead cells were visualized by staining with trypan blue. This procedure caused the death of about $15 \%$ of the isolated cells. Living cells were seeded in Labteck chambers at a density of 40,000 cells/well. Each well was previously coated with poly-Llysine (mol. wt. $>300,000$ ), laminin, or fibronectin, and received $300 \mu \mathrm{L}$ of culture medium renewed every 2 days. At the end of the culture period, cells were fixed and processed for immunostaining or in situ hybridization.

Cells grown in vitro were identified as Schwann cells by their immunoreactivity to antibodies directed against the S100 protein (polyclonal; Novocastra, Newcastle, UK) or its subunit S100b (monoclonal; Sigma), a Schwann cell specific protein in peripheral nerves.

Fibroblast contamination was determined at 2 and 7 days in vitro (div) in control condition (poly-L-lysine coating and unsupplemented defined medium). This determination was carried out by double staining with Schwann cell specific antibodies (anti-S100) and fibroblast selective antibodies recognizing Thy1.1 (monoclonal; Serotec, Oxford, UK; Fig. 3 ). Such double staining indicated that cultured cells were composed of more than $98 \%$ Schwann cells at both 2 and 7 div. Immuno-purification using Thy1.1 antibody prior to seeding did not improve significantly the purity of the Schwann cell culture. In addition, the lack of fibroblast contamination was systematically verified in all experimental cultures where cells were exposed to extracellular matrix proteins or hormones or growth factors. Finally, putative endothelial cell contamination was verified by exposing the cells to an anti-CD31 antibody (CD31: platelet-endothelial cell adhesion molecule-1; Becton Dickinson, San Jose, CA). No endothelial cells were seen (Fig. 3).

\section{Counting Procedure}

At the end of the culture, S100 immunoreactive cells $\left(\mathrm{S}_{100}{ }^{+}\right.$cells) were counted in five $0.322 \mathrm{~mm}^{2}$ wide fields taken at random. A mean value was obtained from these five counts from which a density of cell per $\mathrm{mm}^{2}$ was calculated. The amount of $\mathrm{S}_{100}{ }^{+}$cell $/ \mathrm{mm}^{2}$ allows the assessment of Schwann cell density in various experimental conditions. In the midterm cultures used in this study, the Schwann cell density reflects both cell survival and proliferation.

Schwann cell proliferation was assessed following the exposition of cultures to 5-bromo-2'deoxyuridine (BrdU; 10 $\mu \mathrm{g} / \mathrm{mL}$ ), which incorporates into the DNA of mitotic cells during $\mathrm{S}$ phase. BrdU treatment was performed for 2 or 7 days because Schwann cells are known to proliferate at a low rate. Potential toxicity induced by the 7 day exposure to BrdU appeared to be moderate because no significant difference in cell density was recorded between BrdU-contain- ing and BrdU-free cultures carried out in control conditions. At worst, this possible toxicity would result in an underestimate of the proliferative responses. Nuclear BrdU incorporation was revealed by a monoclonal anti-BrdU antibody (Becton Dickinson), and proliferation rate was measured following double staining against S100 protein and BrdU and was expressed as a labeling index (LI): number of both S100-and BrdU-positive cells/total number of $\mathrm{S} 100^{+}$cells, in an area of $0.322 \mathrm{~mm}^{2}$.

\section{Effects of Substrates and Growth- Promoting Substances on Cell Density and Proliferation}

Effects of substrates and growth-promoting substances on cell density and proliferation were assessed on vestibular and sciatic Schwann cells after a 7 day treatment with these molecules. The following coating molecules were used: poly-L-lysine, laminin, and fibronectin. Tested growth-promoting agents were: N2 supplement (Gibco Invitrogen), forskolin (Calbiochem, La Jolla, CA), 8 Br-cAMP, epidermal growth factor (EGF; Becton Dickinson), transforming growth factor $\alpha$ (TGF $\alpha)$, insulin, insulinlike growth factor 1 (IGF-1), neurotrophin 3 (NT-3; Abcys, Paris, France), glial cell line derived growth factor (GDNF; Abcys), nerve growth factor (NGF) 7S (Promega, Madison, WI), brain derived growth factor (BDNF; Promega), heregulin $\beta 1$ (NeoMarkers, Fremont, CA), glial growth factor 2 (GGF-2; a gift of Dr. M. Marchioni, Cambridge Neuroscience, Cambridge, MA), fibroblast growth factor 2 (FGF-2; a gift of Dr H. Prats, Hôpital Rangueil, Toulouse, France), progesterone, and platelet-derived growth factor BB (PDGF-BB; Pepro Tech, Rocky Hill, NJ). Schwann cell responses were quantified and given as means \pm SEM of data obtained from about six individual determinations, each determination being the mean of duplicated assays. The statistical significance of data was established by means of Student's $t$ test.

\section{Phenotypic Characterization}

Phenotypic characterization of vestibular Schwann cells was conducted using a panel of antibodies recognizing various Schwann cell antigens: S100, S100b, p75 low affinity neurotrophin receptor (polyclonal; Chemicon, Temecula, CA), NCAM (monoclonal; Sigma), GFAP (monoclonal; Sigma), NF2 protein (also named merlin or schwannomin, monoclonal; Transduction Laboratories, Lexington, KY), MBP (monoclonal; Serotec), and a riboprobe for the myelin-specific P0 protein mRNAs (P0 cDNA was kindly provided by Dr G. Lemke, Salk Institute, San Diego, CA).

\section{Immunocytochemistry}

Nerves were dissected out of 6-and 13-day-old Wistar rats and fixed by immersion in $4 \%$ paraformaldehyde in phos- 
phate buffered saline (PBS) for $1 \mathrm{~h}$ at room temperature. Once rinsed in PBS, tissues were embedded in $4 \%$ low gelling point agarose in PBS and sectioned with a vibrating blade microtome. Seventy-micron thick sections were used free-floating. Permeabilization and saturation of unspecific binding sites were carried out, as a single step, in Tris/ $\mathrm{NaCl}$ buffer (100 mM/250 $\mathrm{m} M$, respectively, $\mathrm{pH}$ 7.4) containing $10 \%$ swine serum (Jackson ImmunoResearch, West Grove, PA), $0.2 \%$ Tween 20 , and $0.1 \%$ Triton $\mathrm{X}-100$. They were then incubated overnight at $4{ }^{\circ} \mathrm{C}$ with specific primary antibodies, rabbit anti-S100 antisera (dilution 1/800) or anti-p75 (1/100), and monoclonal antibodies, anti-S100b (1/800), anti-MBP (1/100), or anti-NCAM (1/100), in a solution of Tris $100 \mathrm{~m} M$ containing $1 \%$ swine serum, $0.02 \%$ Tween 20 , and $0.01 \%$ Triton X-100. Primary antibody bindings were revealed by corresponding fluorescein or Texas Red conjugated antibodies (1/500, donkey antimouse or antirabbit antibodies; Jackson ImmunoResearch). Stained tissues were mounted in Fluorsave (Calbiochem) before observation using conventional epifluorescence microscopy or laser scanning confocal microscopy (MRC 1024; Bio-Rad). Confocal images were obtained by averaging 10 scans of $0.25 \mu \mathrm{m}$ thick optical sections.

Cultured Schwann cell immunostaining was processed in a similar way apart from the following adaptations: fixation in 4\% paraformaldehyde in PBS lasted only $30 \mathrm{~min}$ at room temperature. For BrdU uptake detection, single stranded DNA was produced after fixation by denaturing DNA with a $\mathrm{HCl} 1 \mathrm{~N}$ treatment (30 min, room temperature) in order to expose incorporated BrdU. BrdU incorporation was revealed by means of a monoclonal anti-BrdU antibody used at the dilution of $1 / 50$ in Tris $100 \mathrm{mM}$. In addition to the above mentioned antibodies, others were also applied on cultures: anti NF2 (1/600), anti-GFAP (1/200), anti-Thy 1.1 $(1 / 200)$, or anti-CD31 (1/800). All primary antibodies were allowed to react on fixed cells for $3 \mathrm{~h}$ at room temperature.

\section{In Situ Hybridization}

Vestibular nerves and Schwann cell cultures were fixed by immersion in 2\% paraformaldehyde in PBS at room temperature for $30 \mathrm{~min}$. Tissues were rinsed in PBS. Nerves were sectioned as indicated above. Sections and cultures were dehydrated with ethanol at increasing concentrations, air dried, and stored at $-20^{\circ} \mathrm{C}$ before use. P0 cDNA was provided subcloned in pcDNAI (Invitrogen), and digoxigenin-labeled sense and antisense probes were generated using, respectively, T7 and SP6 RNA polymerase, following the manufacturer's protocol (SP6/T7 DIG RNA labeling kit; Roche). Riboprobe hybridization was carried out overnight in a mixture of Amersham RPN3310 buffer and formamide $(1 / 1)$ at $55^{\circ} \mathrm{C}$ in moist chambers. Sections and cultures were washed twice with $0.1 \times \mathrm{SSC}(300 \mathrm{~m} M$ sodium chloride, 30 $\mathrm{m} M$ sodium citrate, $\mathrm{pH} 7)$ at $55^{\circ} \mathrm{C}$ for $30 \mathrm{~min}$. Unspecific binding was prevented by treating the tissues, for $30 \mathrm{~min}$ at room temperature, with a Tris- $\mathrm{HCl} /$ sodium chloride buffer $(0.1 M / 0.15 M$, pH 7.5) containing $0.1 \%$ of blocking reagent 1096176 (Roche) and $0.003 \%$ Triton X-100. Digoxigenin detection was undertaken with alkaline phosphatase conjugated antibodies (dilution 1/750; Roche) that were allowed to react for $30 \mathrm{~min}$ at $37^{\circ} \mathrm{C}$. Hybridized riboprobes were revealed by a $20 \mathrm{~h}$ long exposure with the alkaline phosphatase chromogenic substrates nitroblue tetrazolium salt and 5-bromo-4-chloro-3-indolyl phosphate (Roche). Sections and cultures were mounted in mowiol and hybridization signal was observed under light microscope.

\section{RESULTS}

\section{Detection of Schwann Cell Related Markers in the Vestibular Nerve}

We focused on establishing some key features of vestibular nerve cells by means of immunocytochemistry and in situ hybridization. Schwann cell related proteins, or their transcripts, were detected in 6-and 13-day-old vestibular nerves. At these two ages, the following identical observations were made: vestibular Schwann cells express S100 protein [Fig. 1(A)], and its S100b subunit [Fig. 1(B)], the adhesion molecule NCAM [Fig. 1(C)], the low affinity NGF receptor p75 [Fig. 1(D)], MBP [Fig. 1(E)], and mRNAs of the major myelin protein P0 [Fig. 1(F)]. Hence, markers of both myelinating and nonmyelinating lineages are synthesized in the vestibular nerve at these stages of development.

\section{Phenotypic Characterization of Vestibular and Sciatic Schwann Cells in Control Cultures}

Two types of Schwann cells are present in control cultures (poly-L-lysine coating and defined medium) from either vestibular or sciatic nerves: spindle shaped or flattened cells. They differ by three main features: morphology, capability to synthesize DNA, and expression of the S100 protein. Indeed, the spindle shaped cells bear bipolar processes and display, quite often, droplet inclusions in their cytoplasm [Fig. 2(A)]. The flattened cells possess cytoplasmic spreads and usually gather in clusters ranging from less than 10 cells to hundreds of cells [Fig. 2(B)]. Concerning mitosis, cells taking up BrdU into their nuclei always belong to the flattened morphotype [Fig. 3(A,B)]. Bipolar cells consistently display a qualitative stronger S100 (or S100b) immunoreactivity than flattened cells and the intensity of the S100 labeling in flattened cells varies [Fig. 3(A,C,E)]. Despite its low level, bona fide staining of flattened cells is observed under both classical epifluorescence and confocal microscopies. Control experiments omitting either primary or secondary antibodies display no signal (data not 

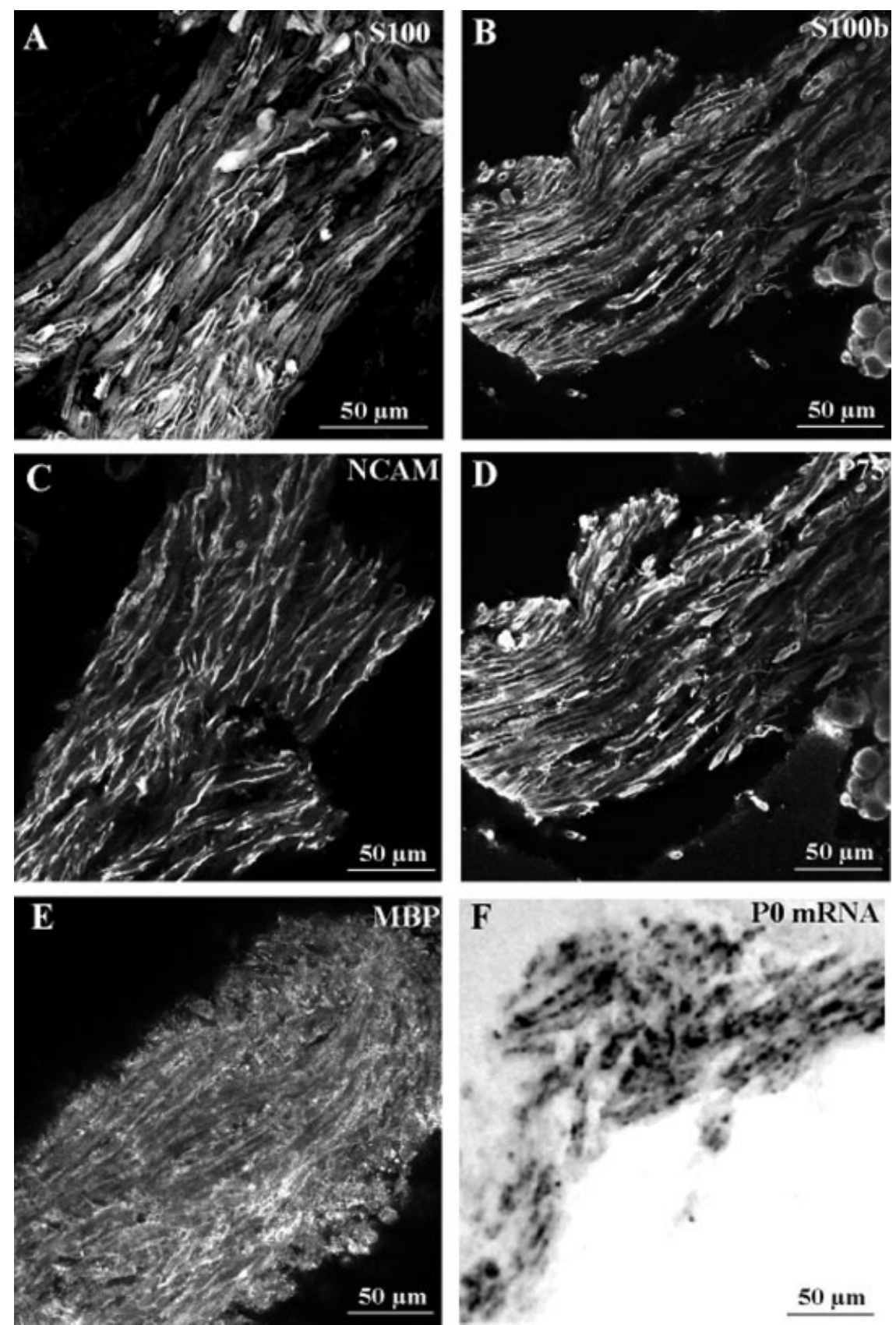

Figure 1 Gross anatomy of 6-day-old rat vestibular nerve depicting in situ detection of Schwann cell markers. Nerves were sectioned and processed for immunostaining or in situ hybridization. Immunoreactivities for S100 protein and its S100b subunit were visualized (A,B) as well as stainings for nonmyelinating markers: NCAM (C) and low affinity neurotrophin receptor p75 (D), and markers of the myelinating lineage: MBP (E) and transcripts of the P0 myelin protein (F). Similar data were obtained in 13-day-old vestibular nerves (not shown).

shown). Furthermore, no staining for the fibroblastic antigen Thy 1.1 or the endothelial protein CD31 was observed (Fig. 3).

Other Markers of Glial Phenotypes. In addition to these main distinctions, the two types of Schwann cells are characterized by differential expressions of other proteins in control cultures (poly-L-lysine coating and defined medium, Figs. 4 and 5). Thus, double stainings using S100 (or S100b) antibodies with other antibodies were undertaken on cultures from both nerve origins. NCAM detection was similar for ves- 

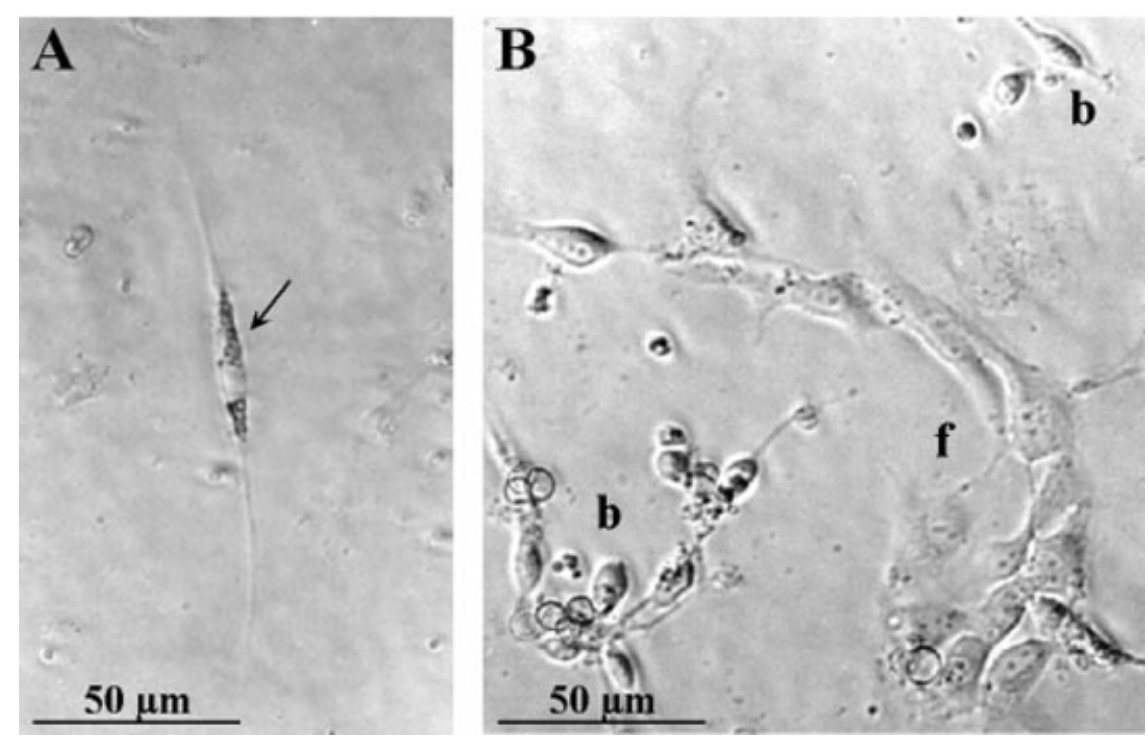

Figure 2 Vestibular Schwann cells in vitro. Cells cultured on poly-L-lysine in DMEM/F12-based defined medium can adopt two morphologies. (A) The typical bipolar spindle shaped cells quite often contain droplet inclusions in their cytoplasm (arrow). (B) In addition to bipolar cells (b), somewhat less shape-specialized cells are also systematically found in culture: flattened cells (f) that produce moderate cytoplasmic spreads and gather in clusters. These pictures are taken from a 4 div-culture but can be found in any assay, throughout the 7 days of the culture period. Similar observations were obtained with sciatic Schwann cells.

tibular and sciatic tissues, in that flattened cells are qualitatively stained at a higher level than bipolar cells [Fig. 4(B,D)]. In contrast, flattened sciatic cells provide a relatively stronger anti-p75 signal than flattened vestibular ones [Fig. 4(H,J)]. GFAP was not detected in vestibular cells while very few sciatic cells express this protein [Fig. 4(I,L)]. Indeed, on average, no more than $10 \mathrm{~S} 100^{+}$cells were GFAP immunoreactive per well (in control condition, a well contains about $400 \mathrm{~S} 100^{+}$cells, see below). Among GFAP synthesizing cells, one finds both bipolar and flattened cells [Fig. 4(K,L)]. Vestibular and sciatic cells of both morphotypes express the NF2 protein [Fig. 4(N,P)]. MBP is absent in vestibular cultures whereas it is detected in sciatic ones [Fig. 5(D)]. At 2 div, in situ hybridization for P0 protein messengers shows that vestibular bipolar cells are the only cells expressing these mRNAs [Fig. 5(E,G)]. At 4 div, no more hybridization signal is observed (data not shown). This indicates that bipolar vestibular cells degrade $\mathrm{P} 0 \mathrm{mR}$ NAs. In addition, this suggests that such down-regulation may be faster in sciatic than in vestibular glia, because, in agreement with the present data, P0 mRNA level was beyond the limits of detection at 2 div in sciatic Schwann cells isolated from 6 day-old rats (Dashiell and Koski, 1999).

In summary, vestibular and sciatic cells mainly differ in the expression of MBP and P0 mRNA; and in both types of culture, only flattened cells proliferate. Vestibular and sciatic cells commonly express the NF2 protein, and this renders them useful for future in vitro studies devoted to understanding why vestibular Schwann cells are more predisposed to schwannomas than other glial cells.

\section{Cell Density, Viability, and Proliferation of Vestibular and Sciatic Cells in Control Conditions}

Time course surveys of the cell density and proliferation of sciatic and vestibular Schwann cells were undertaken in control cultures (poly-L-lysine coating and defined medium). Cell density and proliferation were quantified as indicated in the Methods section with no discrimination between flattened and bipolar morphotypes.

Cell Density. During the first 2 days following plating, an acute period of cell death occurs, causing the cell density to fall to a low level [Fig. 6(A)]. This early cell death may concern serum-starved fibroblasts in addition to Schwann cells, because dishes contain $98 \%$ of $\mathrm{S} 100^{+}$cells at 2 and 7 div (see Methods). After the first $48 \mathrm{~h}$, sciatic and vestibular cell densities are similar and do not significantly vary, 

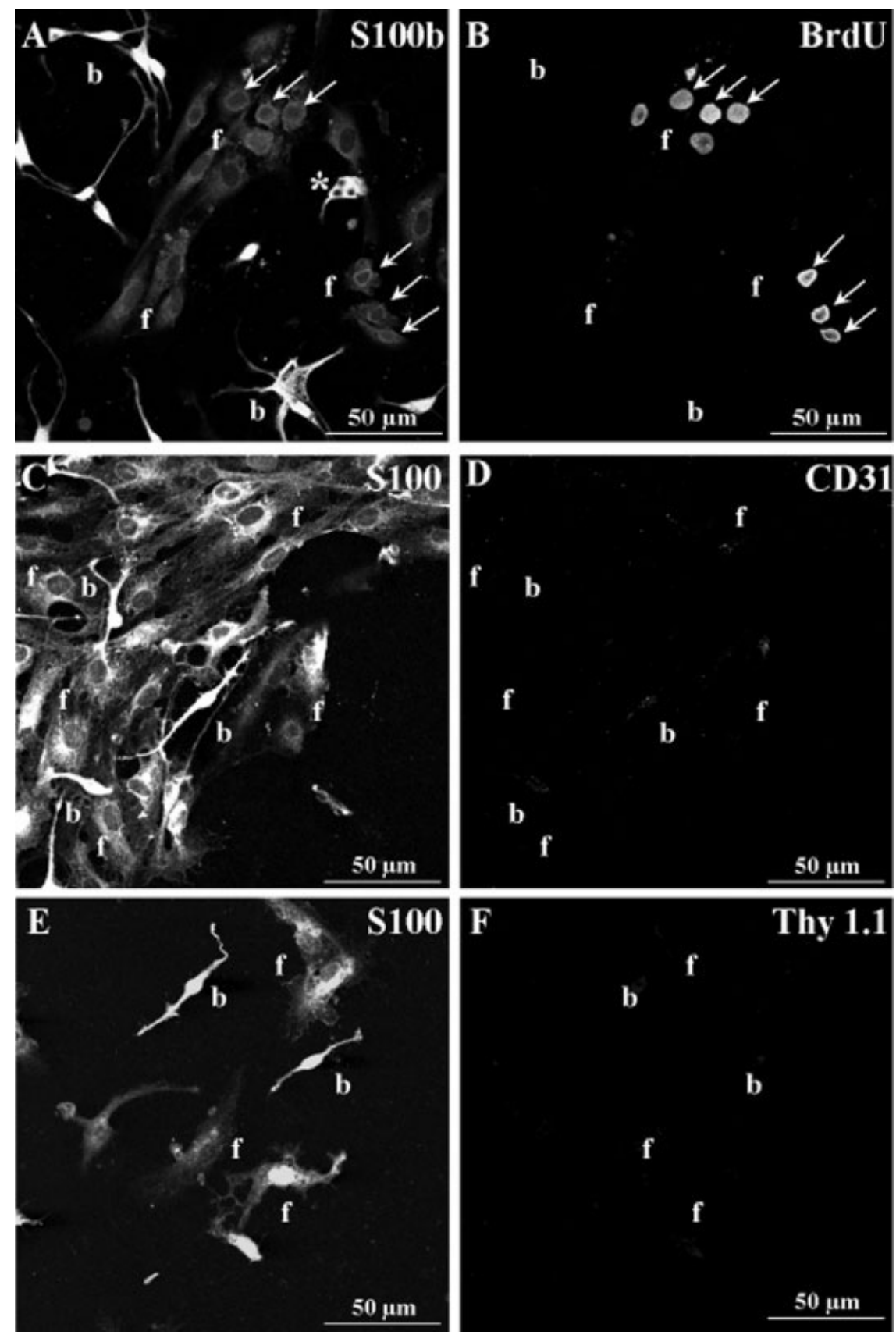

Figure 3 Proliferating cells belong to the flattened morphotype. Vestibular cultures undertaken in control conditions (poly-L-lysine coating, DMEM/F12-based defined medium) were treated with BrdU, subjected to double staining for S100b subunit and BrdU at $7 \mathrm{div}$, and observed under confocal microscopy. (A) Bipolar cells (b) are strongly reactive to antibodies against S100b, while a weak but genuine signal reveals the flattened cells (f). Note the cytoplasmic inclusions in a strongly $\mathrm{S} 100 \mathrm{~b}^{+}$cell (asterisk). Similar differential staining between bipolar and flattened cells is obtained using antisera to the whole $S 100$ protein that produces, on occasion, a stronger labeling of flattened cells than the S100b antibody [see (C) and (E)]. (B) Immunodetection of BrdU indicates that DNA synthesis is restricted to some but not all flattened cells [arrows in (A) and (B)], whereas none of the bipolar strongly S100b ${ }^{+}$cells incorporate BrdU. (C,D) Seven div culture double stained against the glial S100 protein and the endothelial CD31 protein reveals that no contaminating endothelial cells are present. (E,F) Seven div culture double stained against S100 protein and the fibroblast antigen Thy 1.1 shows the absence of fibroblasts. Similar observations were obtained with sciatic Schwann cells. 

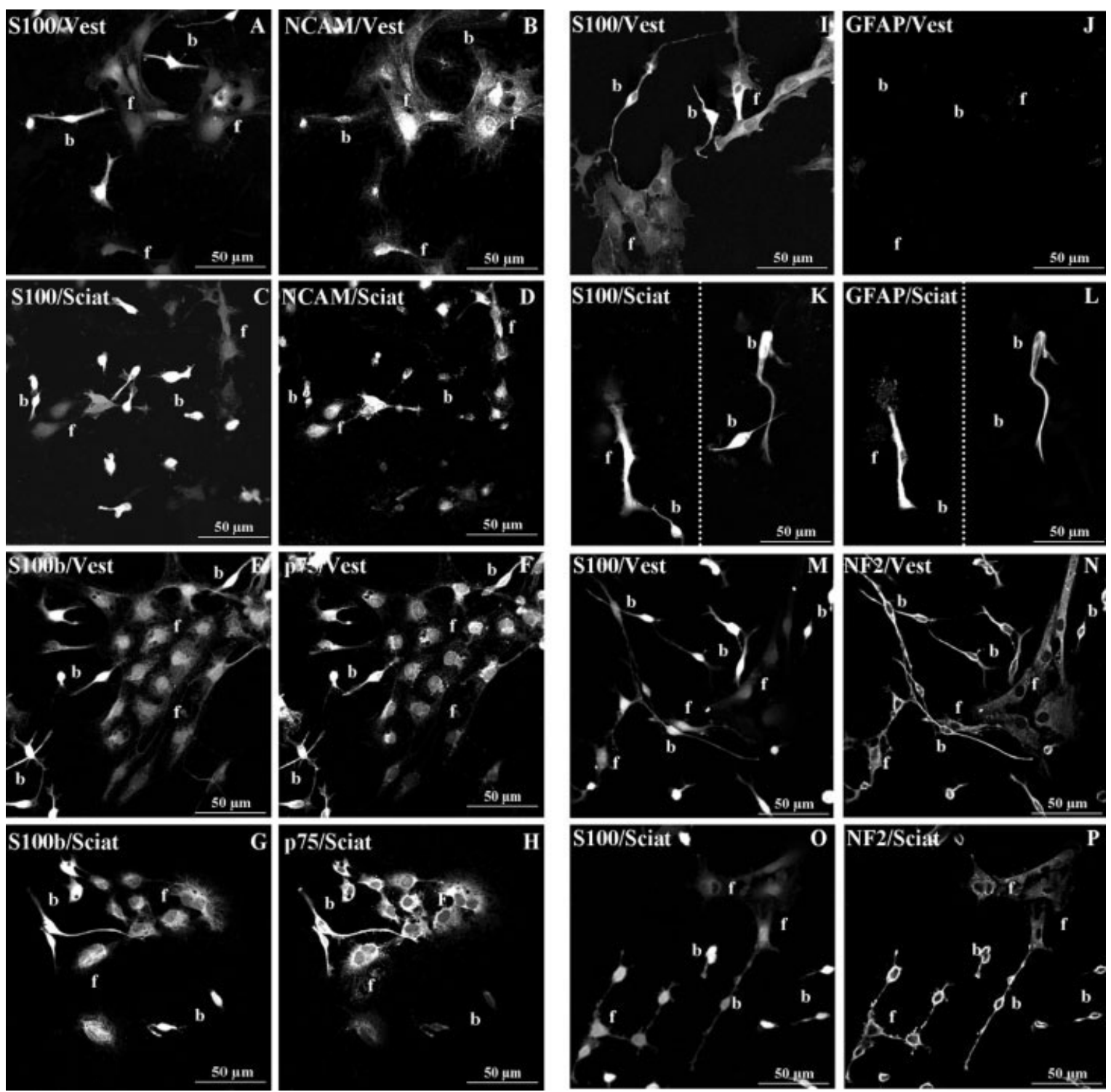

Figure 4 Expression of proteins related to nonmyelinating Schwann cells and to schwannoma in vestibular and sciatic cells. Cells were grown in DMEM/F12-based defined medium, on poly-Llysine for 7 days. Double labeling of cells for S100 (A,C,I,K,M,O) or S100b proteins (E,G) on one hand, and for NCAM (B,D), p75 low affinity neurotrophin receptor (F,H), GFAP (J,L), or the schwannoma related protein NF2 (N,P) on the other hand are shown. NCAM expression is observed in flattened cells (f) at a higher level than in bipolar cells (b) whatever their origin: vestibular (B) or sciatic (D). Cells treated with antisera against the 75 receptor provide a positive signal in both vestibular $(\mathrm{F})$ and sciatic $(\mathrm{H})$ cultures; however, staining in flattened sciatic cells appears stronger than in vestibular ones [ $\mathrm{f}$ in $(\mathrm{F})$ and $(\mathrm{H})]$. GFAP is not detected in vestibular cultures $(\mathrm{J})$ and very few sciatic cells are GFAP immunopositive [about 10 cells per well (L)]. Amongst $\mathrm{S}_{100}{ }^{+}$and $\mathrm{GFAP}^{+}$sciatic cells both bipolar [(K) and (L), right panel] and flattened cells [(K) and (L) left panel] are present. Note that $(\mathrm{K})$ and $(\mathrm{L})$ are montages of two fields separated by the vertical dotted line. The schwannoma related NF2 protein is synthesized by both vestibular and sciatic S100+ cells [(M) to $(\mathrm{P})$ ]. Vest, vestibular culture; Sciat, sciatic culture.

as indicated by statistical analyses. For instance, at 7 div, the densities of cell are $52 \pm 5$ and $47 \pm 3{\mathrm{~S} 100^{+}}^{+}$ cells $/ \mathrm{mm}^{2}$ for vestibular and sciatic cultures, respec- tively. This corresponds to an average number of 400 cells/well.

Viability of cells at 7 div was demonstrated by 

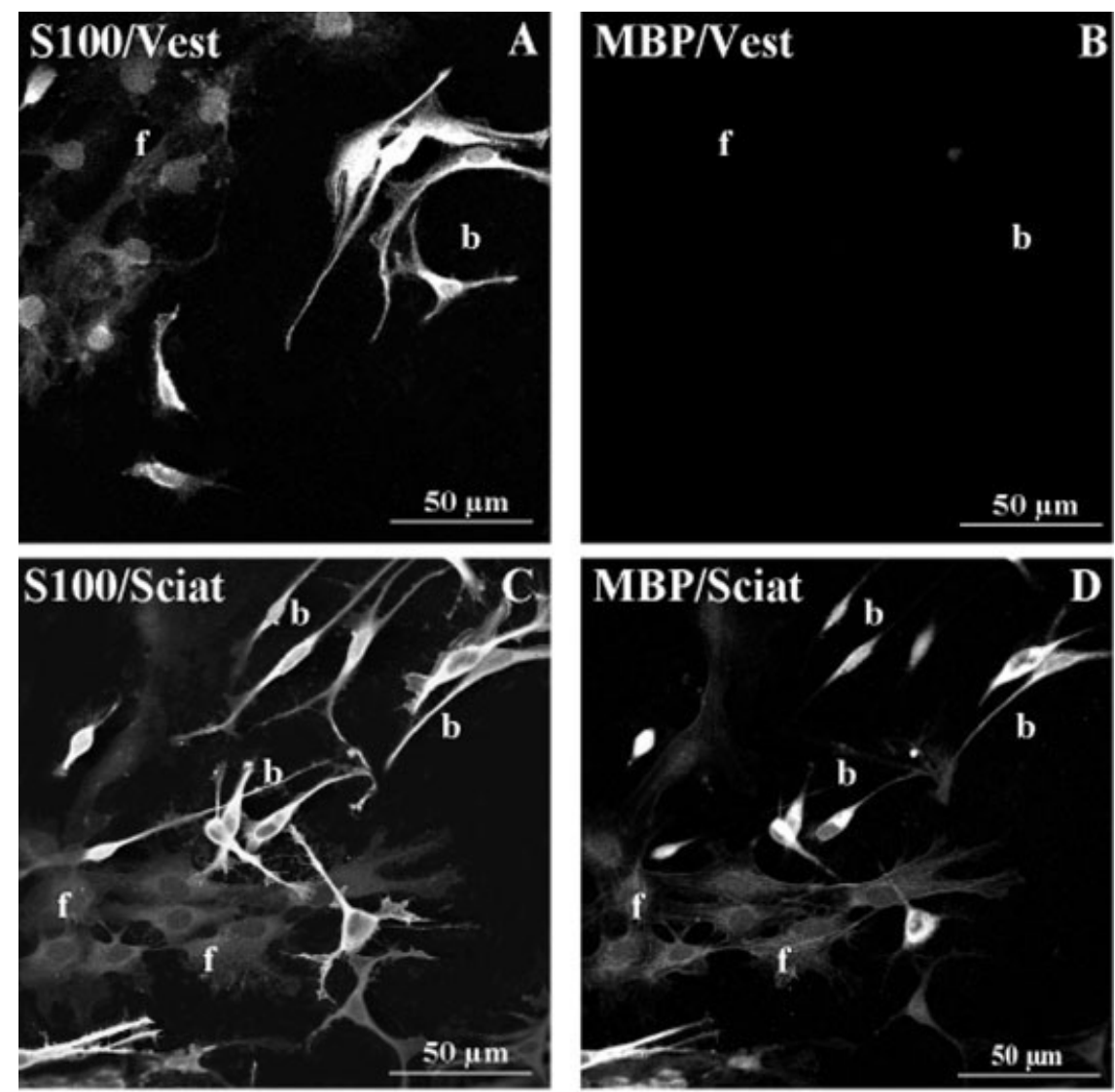

P0 mRNA/Vest

E sense/Vest

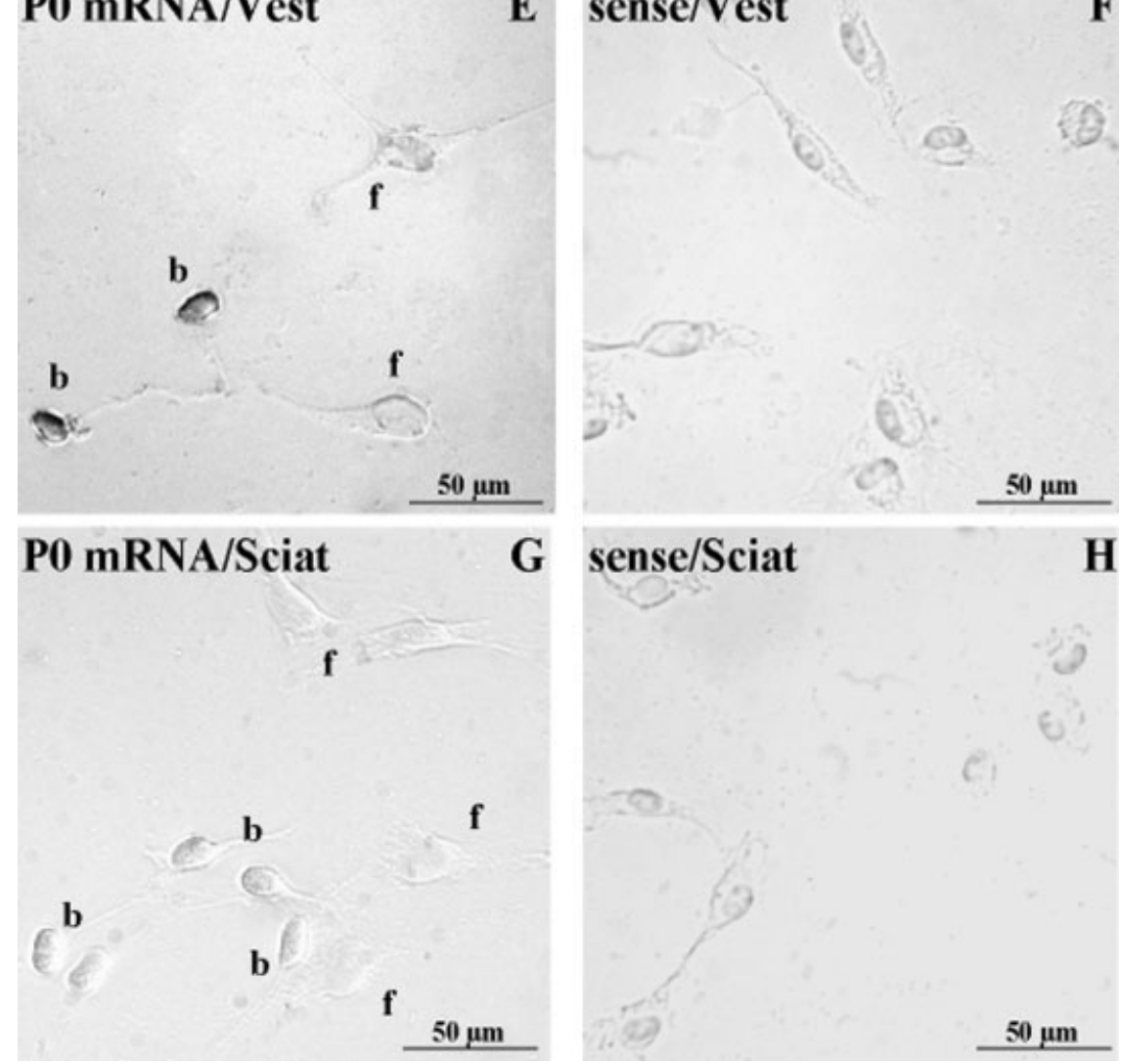

Figure 5 
their ability to take up calcein-AM and to exclude ethidium homodimer-1. All $\mathrm{S} 100^{+}$cells appeared to be healthy [Fig. $6(\mathrm{C}-\mathrm{F})]$. The amount of dead cells was recorded by counting the ethidium homodimer-1 stained nuclei. In vestibular culture, a density of 15 \pm 2 ethidium $^{+}$nuclei $/ \mathrm{mm}^{2}$ is observed. In sciatic cultures, the density reaches $25 \pm 4$ ethidium $^{+}$nuclei/ $\mathrm{mm}^{2}$. Hence, at $7 \mathrm{div}$, the amount of dead cells is higher in sciatic cultures than in vestibular ones ( $p$ $<0.05, n=14$ for each type of culture).

Proliferation. The level of BrdU incorporation remains statistically constant in vestibular cells [Fig. 6(B)]. This is not the case for sciatic cells, whose mitotic rate significantly rises with time. Indeed, a threefold increase in LI occurs from 2 to $7 \mathrm{div}$ (LI: $0.13 \pm 0.02$ to $0.38 \pm 0.05, p<0.001)$. Comparing BrdU incorporation between the two cell types reveals higher mitotic rates in sciatic cells than in vestibular cells at 4 and $7 \mathrm{div}$ (LIs respectively are: $0.32 \pm 0.04$ vs. $0.21 \pm 0.03, p<0.05$, and $0.38 \pm 0.05$ vs. 0.19 $\pm 0.03, p<0.01)$.

In summary, sciatic cells appear to die more than vestibular cells in control conditions. But this cell death is compensated for by a higher proliferation of sciatic cells than their vestibular counterparts. Consequently, vestibular and sciatic cell densities reach similar levels.

\section{Effects of Substrate Proteins on Cell Density, Proliferation, and Phenotype of Vestibular and Sciatic Schwann Cells}

Cell Density. Effects of the extracellular matrix components, laminin, fibronectin (each at $10 \mathrm{ng} / \mathrm{mL}$ ), or a combination of laminin and fibronectin (50\% each), on the number of cells per well were assessed at $7 \mathrm{div}$

Figure 5 In vitro expressions of markers of the myelinating lineage in vestibular and sciatic cells. Double immunostainings were performed in order to reveal the expression of $\mathrm{MBP}$ in $\mathrm{S}_{100}{ }^{+}$cells grown in control conditions (DMEM/ F12-based defined medium, poly-L-lysine coating) at $7 \mathrm{div}$ (A-D). Vestibular Schwann cells fail to synthesize MBP (B). Unlike the latter, sciatic cells predominantly produce MBP (D) in the bipolar morphotype (b), while a weak signal is detected in flattened cells (f). Putative synthesis of the major myelin protein P0 was indirectly assessed by in situ hybridization carried out with riboprobes at 2 div. P0 mRNAs are detected solely in bipolar vestibular cells (E). No hybridization signal appears in sciatic culture $(G)$. Cultures hybridized with the sense $\mathrm{P} 0$ riboprobe are depicted in $(\mathrm{F})$ and $(\mathrm{H})$. Vest, vestibular culture; Sciat, sciatic culture.
[Fig. 7(A)]. Cells were grown in serum free medium (see Methods), and poly-L-lysine was used as control substrate, because vestibular and sciatic cell densities are similar on this substrate [Fig. 6(A)]. Concerning vestibular cells, laminin alone or coated with fibronectin does not alter their density with respect to the level obtained on poly-L-lysine $\left(52 \pm 5 \mathrm{~S} 100^{+}\right.$ cells $\left./ \mathrm{mm}^{2}\right)$. Fibronectin alone reduces vestibular cell density by 2.5 -fold $\left(21 \pm 5 \mathrm{~S}_{100}{ }^{+}\right.$cells $/ \mathrm{mm}^{2}, p$ $<0.001)$. For sciatic cells, laminin significantly enhances the number of cells per surface unit from 47 \pm 3 (control) to $68 \pm 7 \mathrm{~S} 100^{+}$cells $/ \mathrm{mm}^{2}(p<0.05)$. Conversely, fibronectin is a poor substrate, decreasing this number to $9 \pm 2 \mathrm{~S} 100^{+}$cells $/ \mathrm{mm}^{2}$ (a fivefold reduction, $p<0.001)$. Sciatic cell density on laminin/ fibronectin mixture $\left(45 \pm 6 \mathrm{~S}_{100}{ }^{+}\right.$cells $\left./ \mathrm{mm}^{2}\right)$ is similar to that on poly-L-lysine coating.

In summary, significant differences exist between vestibular and sciatic cell densities on laminin and the mixture laminin/fibronectin. Laminin is a better substrate for sciatic glia $\left(68 \pm 7\right.$ vs. $39 \pm 4 \mathrm{~S}_{100^{+}}$ cell $/ \mathrm{mm}^{2} p<0.01$ ) whereas laminin/fibronectin combination produces a reverse difference, because density is higher for vestibular cells than for sciatic ones $\left(73 \pm 11\right.$ and $45 \pm 6 \mathrm{~S} 100^{+}$cell $/ \mathrm{mm}^{2}$ respectively, $p$ $<0.05)$.

Proliferation. In 7-day vestibular cultures, laminin does not alter BrdU incorporation ( $\mathrm{LI}=0.13 \pm 0.01$ ) with respect to control incorporation measured on poly-L-lysine $(\mathrm{LI}=0.19 \pm 0.03)$ [Fig. 7(A)]. The combination fibronectin/laminin decreases significantly BrdU uptake (LI $=0.10 \pm 0.01, p<0.01$ ), whereas fibronectin on its own significantly enhances proliferation $(\mathrm{LI}=0.28 \pm 0.01, p<0.05)$.

As for sciatic cells, control conditions favor BrdU incorporation because other coatings significantly reduce LIs. Thus, for these cells, the rank order of mitogenic potency is: poly-L-lysine $(\mathrm{LI}=0.38$ $\pm 0.05)>$ laminin/fibronectin $(\mathrm{LI}=0.19 \pm 0.02, p$ $<0.001)=$ laminin $(\mathrm{LI}=0.24 \pm 0.02, p<0.05)$ $>$ fibronectin $(\mathrm{LI}=0.09 \pm 0.03, p<0.001)$.

Statistical differences are evident between vestibular and sciatic levels of BrdU incorporation for all substrates (significances are $p<0.01$ for poly-Llysine and laminin/fibronectin and $p<0.001$ for laminin and fibronectin). Hence, coating-elicited mitogenic responses of these cells differ in vitro.

Phenotype. Cultured Schwann cells express various glial markers in control conditions (see above, Figs. 4 and 5). Such expression was challenged by seeding the cells on laminin or fibronectin. In both cases, expressions of $\mathrm{P} 0$ mRNA and p75 are unchanged 

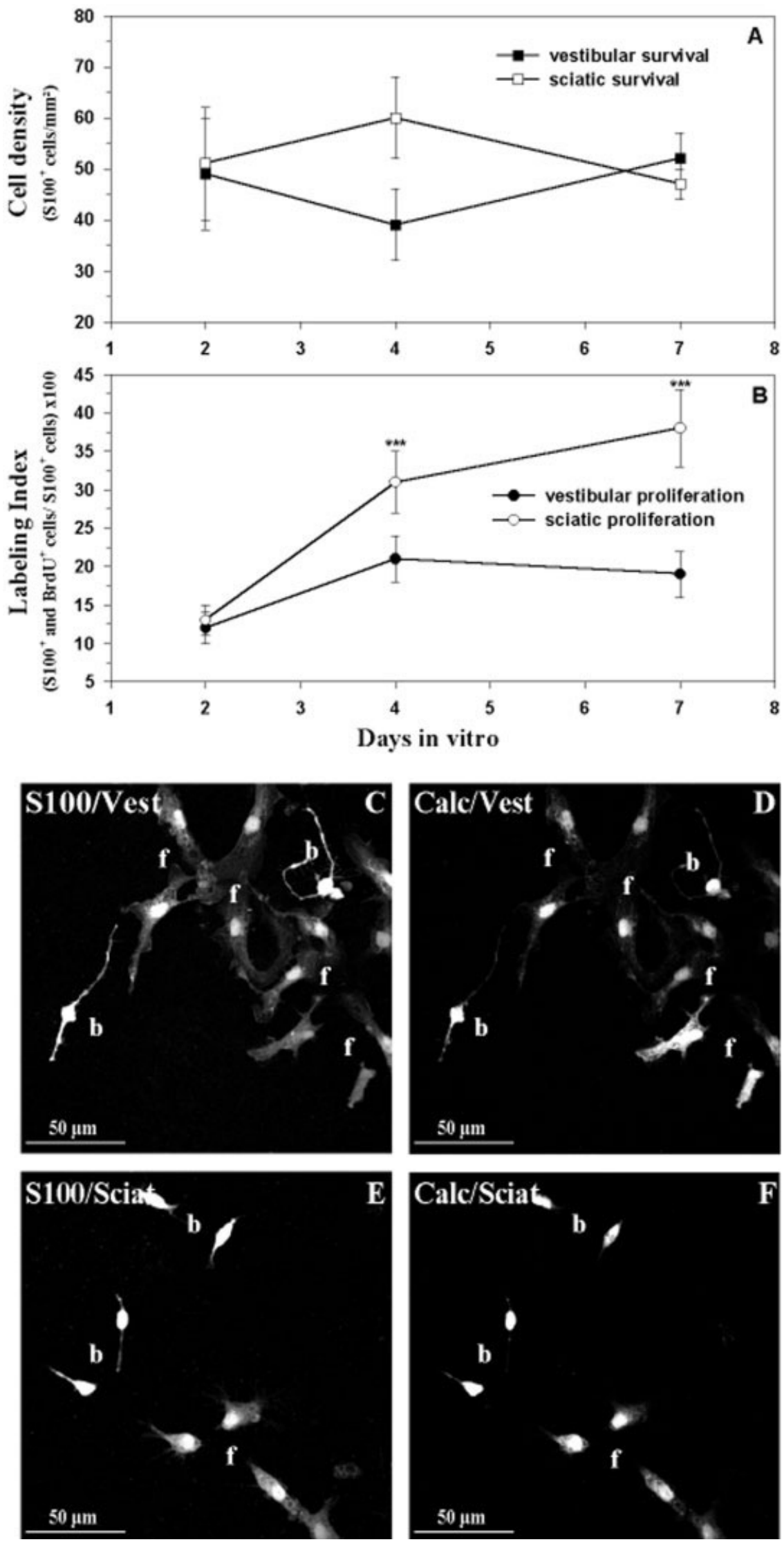

Figure 6 

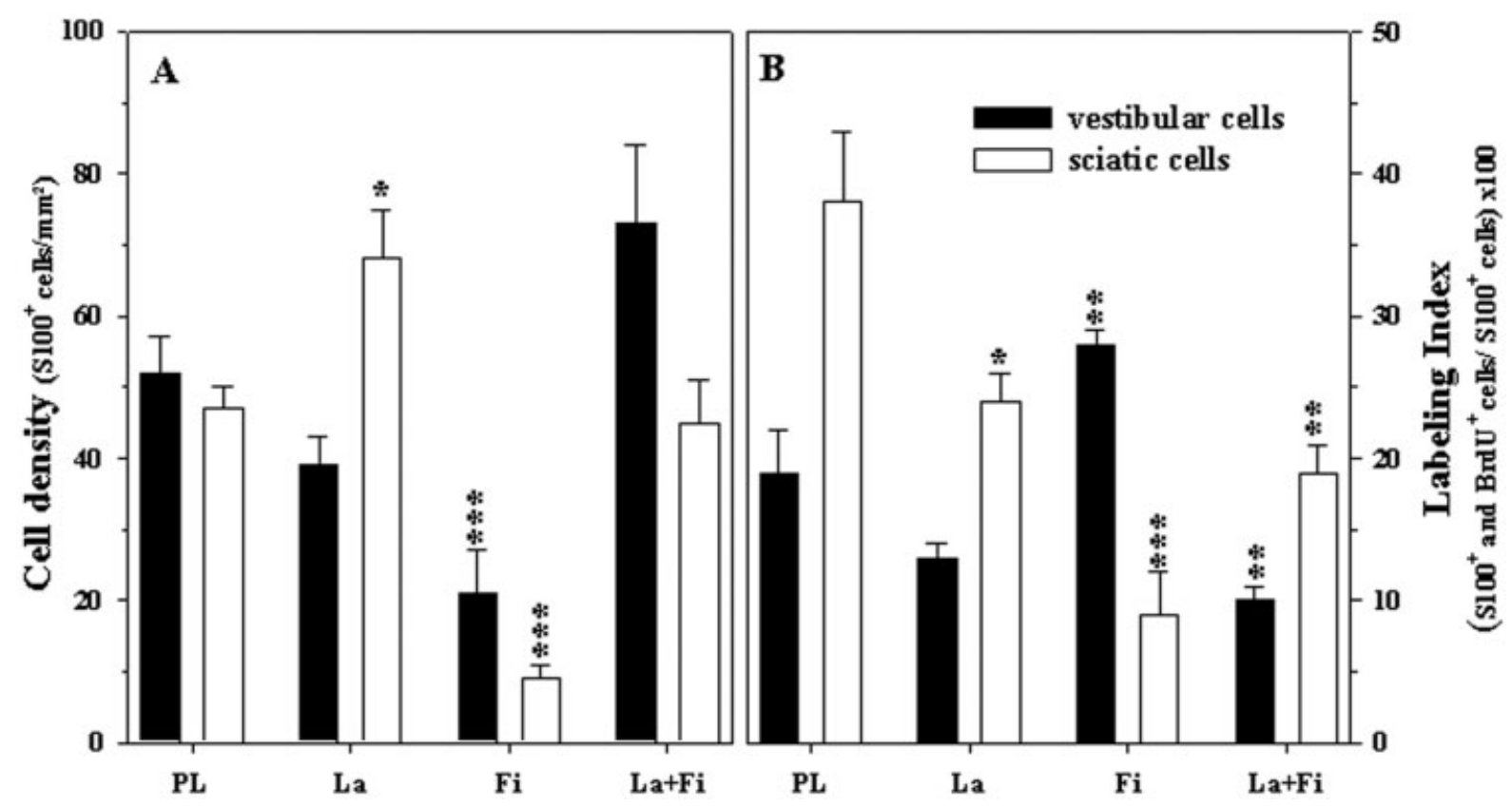

Figure 7 Effects of substrate proteins on cell density and proliferation of vestibular (black bars) and sciatic (white bars) Schwann cells. Cell density (A) and proliferation, expressed as labeling index (B), were recorded, at $7 \mathrm{div}$, in cultures grown in DMEM/F12-based defined medium on poly-L-lysine (PL, control), laminin ( $\mathrm{La})$, fibronectin (Fi), or the mixture of laminin and fibronectin $(\mathrm{La}+\mathrm{Fi})$. Data are means $\pm \mathrm{SEM}$ of at least four independent determinations carried out in duplicates. $* p<0.05,{ }^{* *} p<0.01, * * * p<0.001$ established with respect to controls carried out on poly-L-lysine. Note, in (B), the 100X magnification of data, as indicated in the $y$ axis title.

(Table 1). In situ hybridization confirms that P0 transcripts are solely synthesized by bipolar vestibular cells at 2 div, the signal disappearing thereafter.

Unlike p75 staining and P0 hybridization, NCAM and MBP expression is altered on those substrates (Table 1). Plating on laminin or fibronectin resulted in

Figure 6 Time courses of cell density variation and proliferation in control vestibular and sciatic cultures grown on poly-L-lysine in DMEM/F12-based defined medium. (A) $\mathrm{S} 100^{+}$cells were visualized and counted, as indicated in "Methods", in order to assess their density at 2, 4, and 7 div. (B) Proliferation, given as labeling index, was determined by means of BrdU incorporation into $\mathrm{S} 100^{+}$cells as indicated in "Methods". These cells were double labeled with S100-and BrdU-directed antibodies. Data are means \pm SEM of at least five independent determinations carried out in duplicates. $* * * p<0.001$ established with respect to data obtained at $2 \mathrm{div}$ in a given set of experiments. Note, in (B), the 100X magnification of data, as indicated in the $y$ axis title. (C-F) Viability of $\mathrm{S} 100^{+}$cells is demonstrated by their ability to incorporate calcein. Vest, vestibular culture (C,D); Sciat, sciatic culture (E,F); Calc, calcein; (b) bipolar cell; (f) flattened cells. an equalization of NCAM staining intensity between flattened and bipolar cells, whatever their origin [this differs from NCAM signal on poly-L-lysine, which is stronger in flattened cells than in their bipolar counterparts; Fig. 4(A-D)]. MBP immunodetection was reduced in sciatic bipolar cells and became similar to that in sciatic flattened cells. However, the most prominent change in MBP expression was that it was switched on by these coatings in both vestibular morphotypes [expression was absent on poly-L-lysine; Fig. 5(A,B)].

\section{Effects of Growth Factors and Other Components on Cell Density of Vestibular and Sciatic Schwann Cells}

These experiments were conducted on poly-L-lysine because this substrate provides similar levels of cell density in the 7-div vestibular and sciatic cultures [Fig. 6(A)]. No attempt was made to quantify cell density between flattened and bipolar morphotypes. Out of 16 substances tested, FGF-2 (10-100 ng/mL), NGF (1-20 ng/mL), and forskolin $(0.1-50 \mu M)$ did not change the density of any cells. Amongst the remain- 
Table 1 Substrate Changes Alter Schwann Cell Phenotypes

\begin{tabular}{|c|c|c|c|c|c|}
\hline \multirow[b]{2}{*}{ Markers } & \multirow[b]{2}{*}{ Morphotypes } & \multicolumn{2}{|c|}{ Poly-L-Lysine } & \multicolumn{2}{|c|}{ Laminin or Fibronectin* } \\
\hline & & Vestibular & Sciatic & Vestibular & Sciatic \\
\hline \multirow{2}{*}{ P0 mRNA } & Flattened & - & - & - & - \\
\hline & Bipolar & + & - & - & - \\
\hline \multirow[t]{2}{*}{ p75 } & Flattened & + & + & + & + \\
\hline & Bipolar & + & + & + & + \\
\hline \multirow[t]{2}{*}{ NCAM } & Flattened & ++ & ++ & + & + \\
\hline & Bipolar & + & + & + & + \\
\hline \multirow[t]{2}{*}{ MBP } & Flattened & - & + & + & + \\
\hline & Bipolar & - & ++ & + & + \\
\hline
\end{tabular}

Cells grown for 7 days in DMEM/F12-based defined medium on poly-L-lysine, laminin, or fibronectin were subjected to in situ hybridization or immunocytochemistry in order to detect P0 mRNA, p75 receptor, NCAM, and MBP. Qualitative levels of signals were given with respect to morphotypes (bipolar vs. flattened) and to nerve origins (vestibular vs. sciatic) as follows: + , present; ++ , strong; - , absent. *Laminin and fibronectin provide identical results that are commonly indicated in a single column.

ing factors, some showed specific effects on one or the other cell type (see below). Lastly, there are unspecific factors that either increase the amount per well of both sciatic and vestibular cells, or are partly selective for a given cell type at a given concentration. These latter molecules have nonspecific effects at increased concentrations. The statistical relevance of differences between vestibular and sciatic responses to tested reagents is given in Table 2 (rightmost column).

Vestibular Factors. NT-3 $(1-10 \mathrm{ng} / \mathrm{mL}, p<0.01)$ and PDGF-BB $(5 \mathrm{ng} / \mathrm{mL}, p<0.01)$ enhance significantly the vestibular cell density, but both growth factors lose their specificity at higher concentrations (Table 2, "unselective agents"). Six substances enhance specifically the density of vestibular Schwann cells (Table 2, "vestibular selective agents"): the N2 supplement, insulin, IGF-1, GDNF, EGF, and GGF-2. N2 supplement contains insulin and progesterone; thus, its effect may be partly mediated by insulin but not by progesterone. Indeed, insulin at $1 \mu \mathrm{g} / \mathrm{mL}$ (about twice its concentration in N2 mixture) increases the vestibular cell density, whereas progesterone used at $5 \mu M$ (250-fold the N2 progesterone concentration) does not alter the number of cells in wells.

Sciatic Factors. FGF-2 combined with forskolin enhances significantly sciatic Schwann cell density, as does progesterone and 8-Br-AMPc (Table 2 "sciatic selective agents"). As for TGF $\alpha$, it promotes the expansion of the sciatic population at $10 \mathrm{ng} / \mathrm{mL}(p$ $<0.01$ ), but it raises both sciatic and vestibular densities at increasing concentrations (Table 2, "unselective agents").

Unspecific Factors. BDNF increases sciatic cell numbers by $50 \%$, but this rise is not statistically different from the BDNF-induced vestibular response. Some proteins increase significantly, but similarly, densities of both glial cell types. These include heregulin $\beta 1$, NT-3, TGF $\alpha$ and PDGF-BB. Statistical significances of their effects are given in Table 2 ("unselective agents"). These data show that vestibular and sciatic Schwann cells require different sets of growth factors to enhance their in vitro cell density.

\section{Mitogenic Effects on Vestibular Schwann Cells}

The mitogenic potential of some factors that enhance vestibular cell density was assessed because proliferation may contribute to their "prosurvival" effects (Fig. 8). Cultures were exposed to BrdU (10 $\mu \mathrm{g} / \mathrm{mL})$ for 2 and $7 \mathrm{div}$. Establishment of LIs showed that none of the tested molecules stimulated the mitotic rate after a 2 day exposure. Following 7 days of treatment, IGF-1 $(50 \mathrm{ng} / \mathrm{mL})$ had no proliferative action on vestibular cells, whereas GGF-2 $(25 \mathrm{ng} / \mathrm{mL})$, GDNF (25 ng/mL), and NT-3 (10 ng/mL) significantly enhanced BrdU incorporation over control (nonsupplemented defined medium, poly-L-lysine coating). Among these substances, GGF-2 is the most powerful mitogen $(\mathrm{LI}=0.55 \pm 0.05, p<0.001)$ followed by NT-3 (LI $=0.32 \pm 0.03, p<0.01)$ and GDNF $(\mathrm{LI}=0.27 \pm 0.02, p<0.05)$.

\section{Sensitivity of Vestibular Morphotypes to Substrate Proteins and Growth Factors}

The proportions of the vestibular bipolar and flattened cell subpopulations remained steady over several days. Indeed, out of the whole $\mathrm{S} 100^{+}$cell population at 2 div, bipolar and flattened morphotypes repre- 
Table 2 Comparison of Vestibular and Schwann Cell Densities after a 7-Day Exposure to Various Factors

\begin{tabular}{|c|c|c|c|}
\hline & $\begin{array}{c}\text { Vestibular Cell Density } \\
\% \text { of Control }\end{array}$ & $\begin{array}{l}\text { Sciatic Cell Density } \\
\% \text { of Control }\end{array}$ & $\begin{array}{l}\text { Statistical Significance } \\
\text { (Vestibular vs Sciatic) }\end{array}$ \\
\hline \multicolumn{4}{|l|}{ Vestibular selective agents } \\
\hline $\mathrm{N} 2(1 \%)$ & $214 \pm 20(p<0.001)$ & $115 \pm 8$ & $p<0.01$ \\
\hline Insulin $1 \mu \mathrm{g} / \mathrm{mL}$ & $135 \pm 8(p<0.05)$ & $113 \pm 8$ & $p<0.05$ \\
\hline Insulin $5 \mu \mathrm{g} / \mathrm{mL}$ & $170 \pm 19(p<0.01)$ & $108 \pm 9$ & $p<0.01$ \\
\hline Insulin $10 \mu \mathrm{g} / \mathrm{mL}$ & $209 \pm 17(p<0.001)$ & $111 \pm 13$ & $p<0.001$ \\
\hline IGF-1 $10 \mathrm{ng} / \mathrm{mL}$ & $132 \pm 15(p<0.05)$ & $98 \pm 6$ & $p<0.05$ \\
\hline IGF-1 $100 \mathrm{ng} / \mathrm{mL}$ & $180 \pm 12(p<0.001)$ & $119 \pm 6$ & $p<0.001$ \\
\hline IGF-1 $500 \mathrm{ng} / \mathrm{mL}$ & $187 \pm 15(p<0.001)$ & $106 \pm 6$ & $p<0.001$ \\
\hline GDNF $10 \mathrm{ng} / \mathrm{mL}$ (inactive at $1 \mathrm{ng} / \mathrm{mL}$ ) & $135 \pm 10(p<0.05)$ & $102 \pm 5$ & $p<0.01$ \\
\hline GDNF $20 \mathrm{ng} / \mathrm{mL}$ & $170 \pm 9(\mathrm{n} p<0.001)$ & $122 \pm 12$ & $p<0.01$ \\
\hline EGF $50 \mathrm{ng} / \mathrm{mL}$ (inactive at $10 \mathrm{ng} / \mathrm{mL}$ ) & $175 \pm 27(p<0.01)$ & $88 \pm 8$ & $p<0.01$ \\
\hline EGF $100 \mathrm{ng} / \mathrm{mL}$ & $172 \pm 36(p<0.05)$ & $129 \pm 21$ & $p<0.01$ \\
\hline GGF-2 $10 \mathrm{ng} / \mathrm{mL}$ & $223 \pm 19(p<0.001)$ & $104 \pm 7$ & $p<0.001$ \\
\hline GGF-2 $25 \mathrm{ng} / \mathrm{mL}$ & $212 \pm 9(p<0.001)$ & $110 \pm 6$ & $p<0.001$ \\
\hline GGF-2 $50 \mathrm{ng} / \mathrm{mL}$ & $266 \pm 15(p<0.001)$ & $134 \pm 6(p<0.05)$ & $p<0.001$ \\
\hline \multicolumn{4}{|l|}{ Sciatic selective agents } \\
\hline FGF-2 $10 \mathrm{ng} / \mathrm{mL}+$ Forskolin $2 \mu M$ & $65 \pm 6(p<0.05)$ & $126 \pm 20$ & $p<0.05$ \\
\hline FGF-2 $50 \mathrm{ng} / \mathrm{mL}+$ Forskolin $2 \mu M$ & $81 \pm 18$ & $212 \pm 32(p<0.001)$ & $p<0.01$ \\
\hline FGF-2 $100 \mathrm{ng} / \mathrm{mL}+$ Forskolin $2 \mu M$ & $109 \pm 18$ & $258 \pm 38(p<0.001)$ & $p<0.01$ \\
\hline FGF-2 $10 \mathrm{ng} / \mathrm{mL}+$ Forskolin $20 \mu M$ & $54 \pm 17(p<0.05)$ & $183 \pm 20(p<0.001)$ & $p<0.001$ \\
\hline FGF-2 $50 \mathrm{ng} / \mathrm{mL}+$ Forskolin $20 \mu \mathrm{M}$ & $63 \pm 19$ & $281 \pm 49(p<0.001)$ & $p<0.01$ \\
\hline FGF-2 $100 \mathrm{ng} / \mathrm{mL}+$ Forskolin $20 \mu M$ & $62 \pm 13(p<0.05)$ & $390 \pm 78(p<0.001)$ & $p<0.01$ \\
\hline Progesterone $5 \mu M$ & $106 \pm 12$ & $172 \pm 24(p<0.05)$ & $p<0.05$ \\
\hline Progesterone $25 \mu M$ & $96 \pm 13$ & $211 \pm 31(p<0.01)$ & $p<0.01$ \\
\hline Progesterone $50 \mu M$ & $108 \pm 20$ & $218 \pm 36(p<0.01)$ & $p<0.05$ \\
\hline 8-Br-AMPc $100 \mu M$ (inactive at $10 \mu M$ ) & $92 \pm 7$ & $200 \pm 30(p<0.05)$ & $p<0.01$ \\
\hline \multicolumn{4}{|l|}{ Unselective agents } \\
\hline Heregulin $50 \mathrm{ng} / \mathrm{mL}$ (inactive at $10 \mathrm{ng} / \mathrm{mL}$ ) & $177 \pm 18(p<0.01)$ & $166 \pm 32$ & \\
\hline Heregulin $100 \mathrm{ng} / \mathrm{mL}$ & $148 \pm 11(p<0.01)$ & $239 \pm 35(p<0.01)$ & $p<0.01$ \\
\hline BDNF $50 \mathrm{ng} / \mathrm{mL}$ (inactive at $25 \mathrm{ng} / \mathrm{mL}$ ) & $142 \pm 27$ & $150 \pm 13(p<0.05)$ & \\
\hline NT-3 1 ng/mL (vestibular selective) & $143 \pm 13(p<0.01)$ & $117 \pm 6$ & \\
\hline NT-3 $10 \mathrm{ng} / \mathrm{mL}$ (vestibular selective) & $179 \pm 22(p<0.01)$ & $129 \pm 9$ & $p<0.05$ \\
\hline $\mathrm{NT}-320 \mathrm{ng} / \mathrm{mL}$ & $173 \pm 19(p<0.001)$ & $150 \pm 20(p<0.05)$ & \\
\hline TGF $\alpha 10 \mathrm{ng} / \mathrm{mL}$ (sciatic selective) & $107 \pm 11$ & $146 \pm 7(p<0.01)$ & $p<0.01$ \\
\hline TGF $\alpha 25 \mathrm{ng} / \mathrm{mL}$ & $128 \pm 12$ & $151 \pm 9(p<0.01)$ & \\
\hline $\mathrm{TGF} \alpha 50 \mathrm{ng} / \mathrm{mL}$ & $146 \pm 9(p<0.05)$ & $169 \pm 11(p<0.01)$ & \\
\hline PDGF-BB $5 \mathrm{ng} / \mathrm{mL}$ (vestibular selective) & $186 \pm 10(p<0.01)$ & $155 \pm 10(p<0.05)$ & $p<0.05$ \\
\hline PDGF-BB $10 \mathrm{ng} / \mathrm{mL}$ & $214 \pm 16(p<0.001)$ & $173 \pm 13(p<0.001)$ & \\
\hline PDGF-BB $20 \mathrm{ng} / \mathrm{mL}$ & $200 \pm 21(p<0.001)$ & $215 \pm 23(p<0.001)$ & \\
\hline
\end{tabular}

Cell density measurement and statistical signification of data were performed as indicated in Methods section. Controls and experimental cultures were grown on poly-L-lysine in DMEM/F12-based defined medium supplemented with factors as indicated. Results are means \pm SEM of at least six determinations and are given as percentage of control densities displayed in Figure 6(A). Significances of differences between vestibular and sciatic evoked-responses are given in the right column. Absence of $p$ value indicates that data are not significantly different from their respective controls.

sented $62 \pm 2$ and $38 \pm 2 \%$, respectively. At 7 div, 59 $\pm 2 \%$ of vestibular cells were bipolar and $41 \pm 2 \%$ were flattened $(100 \%=250$ cells $)$. As for sciatic cells, their morphotype distribution was $58 \pm 2 \%$ of bipolar cells and $42 \pm 2 \%$ of the flattened counterparts at 7 div. Therefore, their distribution was similar to the vestibular one.

Because different coatings affect Schwann cell phenotypes (Table 1), we assessed whether such alterations may exert some influence on the breakdown of the vestibular population according to morphotypes, at 7 div.

Substrates. Compared to poly-L-lysine, distribution of vestibular cells into morphotypes is unaffected by laminin alone or combined with fibronectin [Fig. 


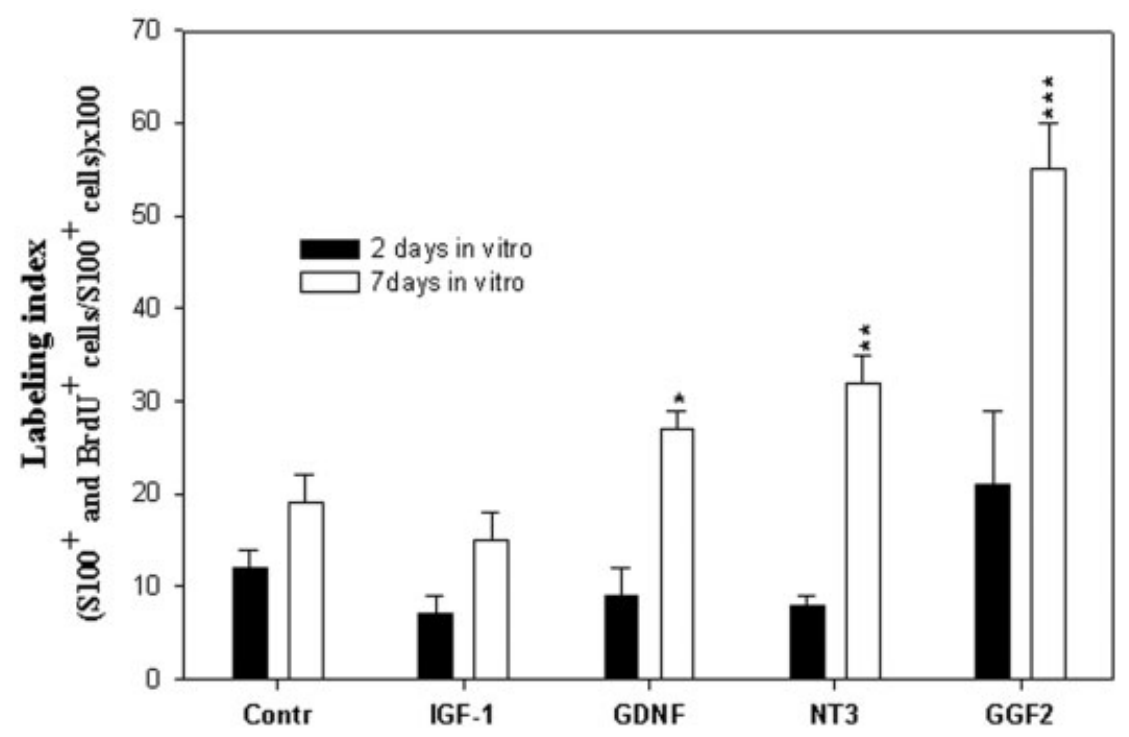

Figure 8 Mitogenic effects of growth factors on vestibular Schwann cells. Cells grown on poly-L-lysine in DMEM/F12-based defined medium were stimulated for 2 or 7 div with mitogens. Proliferation levels were determined by means of BrdU incorporation in $\mathrm{S}_{100}{ }^{+}$cells and expressed as labeling index. Data are means \pm SEM of at least four independent determinations carried out in duplicates. ${ }^{*} p<0.05, * * p<0.01, * * * p<0.001$ established with respect to control (DMEM/F12based defined medium without mitogen, poly-L-lysine coating). Note, the $100 \mathrm{X}$ magnification of data, as indicated in the $y$ axis title.

9(A)]. But laminin increases the length of bipolar cell processes. Indeed, processes that are two-to threefold the length of the soma on poly-L-lysine reach four-to sixfold the length of the soma on laminin (no change in cell body size was recorded). Similar lamininmediated process elongation also occurs in cultured olfactory ensheathing cells (Pixley, 1992). The impact of fibronectin on the morphotype subpopulations was not recorded, because, on its own, it fails to maintain the cell density at a level at least equivalent to control [Fig. 6(A)].

Growth Promoting Agents. For this set of experiments, cells were grown on poly-L-lysine in plain medium (control) or supplemented mediums [Fig. 9(B)]. When N2 mixture (1\%) or IGF-1 (50 ng/mL) was added, no significant changes were recorded in the bipolar/flattened cell proportions. GGF-2 (25 ng/ $\mathrm{mL}$ ) favored the bipolar type, causing an increase of the population up to $70 \pm 2 \%(p<0.01)$. However, GGF-2-treated bipolar cells have rounded soma and differ in this way from their control counterparts, which have spindle shaped soma. Likewise, under GGF-2 exposure, the tips of bipolar processes tend to spread into a growth-cone-like structure. The other tested factors NT-3 $(25 \mathrm{ng} / \mathrm{mL})$, GDNF $(25 \mathrm{ng} / \mathrm{mL})$, and PDGF-BB $(5 \mathrm{ng} / \mathrm{mL})$ enhanced the flattened sub- population, which, respectively, rose to $49 \pm 1 \%(p<$ $0.01), 52 \pm 1 \%(p<0.001)$, and $58 \pm 1 \%(p$ $<0.001)$ of the whole $\mathrm{S} 100^{+}$cell population.

\section{DISCUSSION}

The present report is the first investigation specifically devoted to the characterization of Schwann cells of the vestibular nerve. Obtained data point to different in vitro responses to exogenous cues between vestibular and sciatic cells. The cell types can be distinguished according to phenotypic markers, proliferation, and cell density regulation requirements. The most striking differences are: P0 mRNA expression and MBP synthesis are restricted to vestibular bipolar cells and to all sciatic Schwann cells, respectively; concerning extracellular matrix, laminin selectively enhances sciatic cell density while fibronectin stimulates vestibular proliferation; and, two distinct sets of specific factors regulate the densities of sciatic and vestibular cells.

\section{Two Morphotypes}

Cultured Schwann Cells Display Shape Plasticity. In our primary culture system, Schwann cells adopt 


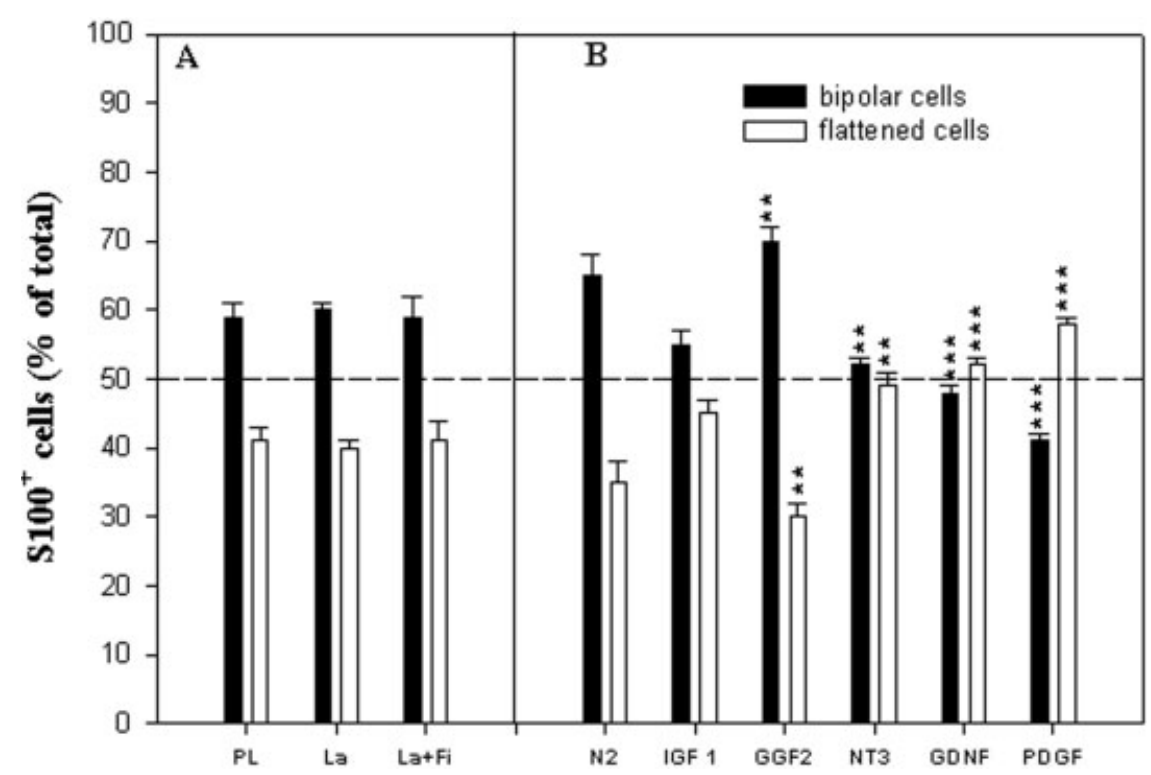

Figure 9 Effects of substrate proteins and growth factors on the distribution of vestibular cells between the two morphotypes. Cells were kept in culture for 7 days in DMEM/F12-based defined medium. During this period, they were exposed to various substrate proteins and growth factors. When the latter were added to the medium, poly-L-lysine was used as coating. Left panel shows the distribution of flattened and bipolar $\mathrm{S} 100^{+}$cells according to coatings with poly-L-lysine (PL, control), laminin (La), and the combination of laminin plus fibronectin ( $\mathrm{La}+\mathrm{Fi}$ ). Right panel depicts alterations in morphotype subpopulation sizes induced by N2 supplement (N2), IGF-1, GGF-2, NT-3, GDNF, and PDGF-BB. Subpopulation sizes are expressed as percentage of a total of $250 \mathrm{~S} 100^{+}$cells observed per well. Data are means $\pm \mathrm{SEM}$ of at least four independent determinations.

two morphologies. The rather classical bipolar shape is found in vitro in postnatal Schwann cells and in neuron/glia coculture (Wood et al., 1990; Jessen et al., 1994; Fernandez Valle et al., 1995, 1997; Chan et al., 2001). The flattened Schwann cell has been described when peripheral glia are immortalized (Goda et al., 1991; Kursula et al., 2001; Lobsiger et al., 2001) or when neuron/glia interactions are disturbed in coculture (Wood et al., 1990). In cultures of ensheathing cells, a unique central glia that shares neurite regeneration-promoting properties with Schwann cells, dual morphology (flattened and process-bearing morphotypes) is also observed (Pixley, 1992; Franceschini and Barnett, 1996; Vincent et al., 2003). These cells display morphological plasticity controlled by reorganizations of their actin network (Vincent et al., 2003). Likewise, in Schwann cells, transition from bipolar shape to flattened morphology involves alterations of the actin-based cytoskeleton (Fernandez Valle et al., 1997; Weiner et al., 2001). It is of note that neuregulins induce cell spreading associated with actin cytoskeleton rearrangements in various cell lines (Chausovsky et al., 2000; Hijazi et al., 2000). Neuregulin-mediated cytoskeleton reorganizations are in- volved in the phenotypic reversion (dedifferentiation) of oligodendrocytes (Canoll et al., 1999) and in the morphological plasticity of ensheathing cells (Chuah et al., 2000). In agreement with these data, we observed that the neuregulin GGF-2 causes both spreading of tips of the bipolar Schwann cell processes and rounding of their soma. Therefore, GGF-2 seems to promote an intermediate Schwann cell morphotype, which mainly differs from the regular bipolar cell by its capability to proliferate. Accordingly, myelinating Schwann cells dedifferentiate and divide in neuron/ glia cocultures once exposed to neuregulins (Zanazzi et al., 2001).

Besides the induction of an intermediate morphotype by GGF-2, other exogenous vectors influence the distribution of flattened and bipolar cells in vestibular cultures. Thus, laminin favors the bipolar phenotype, as it does on sciatic cells (Baron-Van Evercooren et al., 1986). Similarly, laminin increases the number of process-bearing ensheathing cells in vitro (Pixley, 1992). In contrast, the mitogens NT3, GDNF, and PDGF-BB increase the proportion of flattened cells in the vestibular population while the antiapoptotic IGF-1 does not. These data are consistent with the 
conclusions that molecules favoring flattened cells also favor mitosis and that flattened cells are proliferative Schwann cells; the reverse being true for bipolar cells.

Flattened Cells Are Reactive Denervated Cells. The clustering of flattened Schwann cells shown here is a typical behavior of this morphotype, because similar cell clustering has also been reported elsewhere (Wood et al., 1990; Goda et al., 1991; Kursula et al., 2001; Lobsiger et al., 2001; Weiner et al., 2001). Likewise, clusters of flattened ensheathing cells develop in midterm cultures of this central glial cell type (Pixley, 1992). Such a flattened shape is also typical of Schwann cell precursors in murine sciatic nerve (Jessen et al., 1994; Lobsiger et al., 2000, 2001). However, flattened cells found in the present cultures are unlikely to be related to Schwann cell precursors despite the fact that they express the low affinity neurotrophin receptor p75 (Jessen et al., 1994). Indeed, in contrast to Schwann cell precursors, these postnatal Schwann cells are immunoreactive to S100 antibodies and survive both at low density and in the absence of neuronal contacts. Flattened cells are not endothelial cells because they do not bind antibodies recognizing CD31. Likewise, flattened cells are not fibroblasts because: they fail to synthesize the Thy 1.1 fibroblastic antigen; they are about five times smaller than nerve fibroblasts grown in identical conditions (S. Bartolami, unpublished data); and nerve fibroblasts do not express Schwann cell markers such as S100b, NCAM, and p75 (Kim et al., 1989). Flattened shape seems to be a morphotype adopted by proliferative denervated Schwann cell in vitro. This idea is further supported by observations that, first, $\mathrm{S} 100^{+}$ flattened cells incorporate BrdU, and second, all Schwann cells adopt the flattened morphotype once they are expanded in serum-treated secondary cultures (S. Bartolami, unpublished data). The latter observation is in agreement with a recent report (Tsiper and Yurchenco, 2002). Finally, the flattening behavior of denervated proliferative Schwann cells occurs in vivo as well as during repair of nerve injury (Son et al., 1996; Love and Thompson, 1998).

Attempts to ascribe to the two morphotypes a relation with the two in vivo Schwann cell phenotypes (myelinating and nonmyelinating) seems at first rather speculative. However, some lines of evidence should be considered: droplet inclusions in bipolar cells may relate them to myelinating glia in the process of myelin degradation (Fernandez-Valle et al., 1995), as do spindle shape, BrdU exclusion, MBP production, P0 mRNAs synthesis, and high S100 expression (Mata et al., 1990; Jessen and Mirsky, 1991; Lemke,
1993; Stewart et al., 1993). Conversely, p75, NCAM, low S100 expression, and ability to easily proliferate point to the flattened cell as a derivative of nonmyelinating cells, which have not completely exited the cell cycle at the studied stage of maturation (Jessen et al., 1987, 1990; Mata et al., 1990; Stewart et al., 1993; Zorick and Lemke, 1996). Concerning GFAP, the lack of its consistent expression in the present cultures is not surprising because it needs permanent input from small axons to be synthesized (Mokuno et al., 1989). In vitro, Schwann cells are GFAP-immunonegative during the first 2 weeks of culture unless they are pre-exposed to serum (Bianchini et al., 1992; Jessen et al., 1990). Anyway, a cautious conclusion is that, whatever the cells they arise from, the flattened type displays a more advanced dedifferentiation than the bipolar type. Looking at the expression of SCIP, Krox 20, Krox 24, and other transcription factors may help to resolve this issue.

\section{Extracellular Matrix Proteins Differently Affect Cell Density and Mitosis Rate}

Laminin and fibronectin are components of the extracellular matrix of sciatic Schwann cells (Tohyama and Ide, 1984). Their effects on cell density regulation and mitosis were assessed by comparison with cells growing on poly-L-lysine. This artificial coating has been demonstrated to be a substrate of choice for postnatal sciatic glia (Porter et al., 1986). Our data extend this finding by showing that poly-L-lysine provides the best mitogenic support for both cell types, apart from fibronectin, which enhances BrdU uptake in vestibular cells. Such a response to fibronectin is in agreement with a better neonatal Schwann cell proliferation on fibronectin than on laminin (Baron-Van Evercooren et al., 1986). Concerning laminin, it produces its most prominent effect on sciatic cell survival. This laminin induced response can be related to the fact that laminin is especially a glial differentiation promoter (Podratz et al., 2001).

\section{Influences of Growth Factors on Vestibular and Sciatic Schwann Cells}

NT-3. NT-3 synthesis is up-regulated during axoninduced proliferation of Schwann cells and NT-3 inhibits differentiation (myelination of axons) of Schwann cells in neuron/glia coculture (Chan et al., 2001). These facts support our observation that NT-3 is a mitogen for vestibular Schwann cells. However, NT-3 does not increase the density of sciatic cells in our neuron-free model, while it induces sciatic glia proliferation in neuron/glia coculture (Chan et al., 
2001). Part of this difference may be due to exposure to axon-derived signals or other factors, including serum, present in Chan's model. Such agents may influence the glial sensitivity to NT-3. It is noteworthy that the present experiments were conducted in absence of serum because it is established that even serum pre-exposure alters the in vitro response of Schwann cells to growth factors (Dong et al., 1997). Another hypothesis is that the autocrine release of NT-3 contributing to sciatic Schwann cell survival (Meier et al., 1999) is ineffective because neurite degeneration down-regulates NT-3 messenger expression in this glia (Funakoshi et al., 1993). Conversely, NT-3 release may be sufficient to saturate the NT-3 binding sites, thus preventing exogenous NT-3 from further enhancing cell density.

Insulin-like Growth Factors. Like NT-3, IGFs take part in the autocrine loop supporting the survival of Schwann cells once the axonal contact is lost (Meier et al., 1999; Syroid et al., 1999). In our model reflecting this situation, IGF-1 is also a survival factor for vestibular Schwann cells (because IGF-1 increases cell density without increasing BrdU uptake), but fails to support the survival of sciatic cells. These apparent discrepancies concerning sciatic cell survival may be explained by differences in time in vitro and cell density (Dong et al., 1997; Meier et al., 1999), and by the observation that IGF-2 is the most potent polypeptide amongst IGFs, taking part in the autocrine survival loop and in Schwann cell proliferation (Svenningsen and Kanje, 1996; Meier et al., 1999). The differential responses to IGFs may be attributable to activations of selective receptors for IGF-1 and IGF-2 (Svenningsen and Kanje, 1996). Furthermore, IGF-1 survival promotion of postnatal sciatic glia has been demonstrated under conditions of serum withdrawal that do not match the current assays (Syroid et al., 1999). Lastly, failure of IGF-1 to promote DNA synthesis in vestibular Schwann cells suggests that the IGF-1-enhanced survival is due to reduced apoptosis, as reported previously (Campana et al., 1999). In the future, one should assess the possibility that IGF-1 may require appropriate IGF binding proteins to develop full survival or mitogenic effects (Hammarberg et al., 1998), proteins that Schwann cells may lack in drastic in vitro conditions.

$P D G F-B B$ and GDNF. Still in agreement with an autocrine sciatic loop, which also involves PDGF-BB (Eccleston et al., 1990; Meier et al., 1999), this trophic substance was found to support survival in both sciatic and vestibular glia (with a greater efficiency in vestibular cells). These data also extend the prosur- vival effect of PDGF-BB previously described in Schwann cell precursors (Lobsiger et al., 2000). Together with data concerning NT-3 and IGF-1, it is conceivable that vestibular Schwann cells sustain their own survival in a fashion similar to that of sciatic non-neuronal cells. But unlike sciatic glia, survival of vestibular glia should involve additional polypeptides such as GDNF, because this factor enhances the vestibular cell density in the present cultures. This possibility is supported by an autocrine growth activity found in IMS32 Schwann cells that produce GDNF mRNAs (Watabe et al., 1995). GDNF mRNAs were detected in primary cultured neonatal Schwann cells (Henderson et al., 1994) and transcripts for GDNF and its receptors are up-regulated after nerve injury (Hammarberg et al., 1996; Höke et al., 2002). The GDNF-induced vestibular glial cell mitosis is in agreement with the recent demonstration that GDNF stimulates Schwann cell proliferation in unmyelinated nerve fibers (Höke et al., 2003).

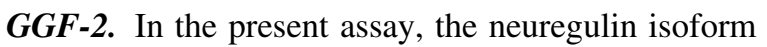
II GGF-2 elicits moderate effects on sciatic cells because it enhances their density only at $50 \mathrm{ng} / \mathrm{mL}$. This relative lack of efficacy may be explained by the fact that GGF-2 is not the main neuregulin involved in the maturation of postnatal sciatic Schwann cells. Indeed, neonatal cultured sciatic Schwann cells weakly produce other neuregulins (isoforms I and III) but no GGF-2 (Raabe et al, 1996; Rosenbaum et al., 1997). Sensory and motor neuronal partners of these cells mainly produce neuregulin isoform III after birth (Ho et al., 1995; Bermingham-McDonogh et al., 1997). Unlike sciatic glia, vestibular Schwann cells are very sensitive to GGF-2 with respect to cell density enhancement and mitogenic response. Moreover, GGF-2 affects vestibular Schwann cells in a singular way compared to GDNF, PDGF-BB, and NT-3. Indeed, while these polypeptides favor the presence of flattened glial cells in vitro, GGF-2 promotes the occurrence of a bipolar morphotype (see above). This peculiar GGF-2 effect may reflect the fact that GGF-2 mainly mediates neuron-to-glia signaling (Marchionni et al., 1993; Verdi et al., 1996; Jessen and Mirsky, 1999; Hansen et al., 2001), whereas the other factors are mainly involved in Schwann-to-neuron communication (Eccleston et al., 1990; Henderson et al., 1994; Watabe et al., 1995; Verdi et al., 1996; Meier et al., 1999; Jessen and Mirsky, 1999; Hansen et al., 2001). Lastly, neuregulins signal through a different transduction pathway than NT-3 or PDGF-BB on a given model (Meier et al., 1999). 


\section{CONCLUSION}

The present data provide an additional set of evidence for the great plasticity of Schwann cells faced with alterations in their extracellular environment. Most importantly, this study shows that vestibular Schwann cells have their own in vitro behavior. This is specifically demonstrated by the fact that vestibular Schwann cell density is controlled by selective cues different from those regulating the sciatic glia population. Together with their relationship with placodal neurons, these results suggest that vestibular Schwann cells form a distinct glial cell population, with specific properties, which may contribute to explain their predisposition to schwannoma. Lastly, because the cultured vestibular Schwann cells synthesize the NF2 protein, which is the target of the schwannoma pathophysiology, they may be a suitable model for the study of the normal function of the NF2 protein within this neurosensory system. Checking the specific impacts of vestibular trophic factors on the molecular interactions involving the NF2 protein in the control of proliferation/differentiation should be the first step of such a study.

We thank Drs P. Carroll, C. Caussidier, G. Desmadryl, G. Devau, I. Mechaly, P Milhau, M.T. Nicolas, and V. Sieso for useful comments on the manuscript.

\section{REFERENCES}

Baron van Evercooren A, Gansmüller A, Gumpel M, Baumann N, Kleinman HK. 1986. Schwann cell differentiation in vitro: extracellular matrix deposition and interaction and motility. J Cell Biol 93:211-216.

Bermingham-McDonogh O, Xu YT, Marchionni MA, Scherer SS. 1997. Neuregulin expression in PNS neurons: isoforms and regulation by target interactions. Mol Cell Neurosci 10:184-195.

Bianchini D, De Martini I, Cadoni A, Zicca A, Tabaton M, Schenone A, Anfosso S, Akkad Wattar AS, Zaccheo D, Mancardi GL. 1992. GFAP expression of human Schwann cells in tissue culture. Brain Res 570:209-217.

Campana WM, Darin SJ, O’Brien JS. 1999. Phosphatidylinositol 3-kinase and Akt protein kinase mediate IGF-1 and prosamide-induced survival in Schwann cells. J Neurosci Res 57:332-341.

Canoll PD, Kraemer R, Teng KK, Marchionni MA, Salzer JL. 1999. GGF/Neuregulin induces a phenotypic reversion of oligodendrocytes. Mol Cell Neurosci 13:79-94.

Chan RJ, Cosgaya JM, Wu YJ, Shooter EM. 2001. Neurotrophins are key mediators of the myelination program in the peripheral nervous system. Proc Natl Acad Sci USA 98:14661-14668.

Chausovsky A, Waterman H, Elbaum M, Yarden Y, Geiger
B, Bershadsky AD. 2000. Molecular requirements for the effect of neuregulin on cell spreading, motility and colony organization. Oncogene 19:878-888.

Chuah MI, Cossins JM, Woodhall E, Tennent R, Nash G, West AK. 2000. Glial growth factor 2 induces proliferation and structural changes in ensheathing cells. Brain Res 857:265-274.

D'Amico-Martel A, Noden DM. 1983. Contributions of placodal and neural crest cells to avian cranial peripheral ganglia. Am J Anat 166:445-468.

Dashiell SM, Koski CL. 1999. Sublytic terminal complement complexes decrease P0 gene expression in Schwann cells. J Neurochem 73:2321-2330.

Dong Z, Dean C, Walters JE, Mirsky R, Jessen KR. 1997. Response of Schwann cells to mitogen in vitro is determined by pre-exposure to serum, time in vitro and developmental age. Glia 20:219-230.

Eccleston PA, Collarini EJ, Jessen KR, Mirsky R, Richardson WD. 1990. Schwann cells secrete a PDGF-like factor: evidence for an autocrine growth mechanism involving PDGF. Eur J Neurosci 2:985-992.

Evans DGR, Sainio M, Baser ME. 2000. Neurofibromatosis type 2. J Med Genet 37:897-904.

Fernandez Valle C, Bunge RP, Bunge MB. 1995. Schwann cells degrade myelin and proliferate in the absence of macrophages: evidence from in vitro studies of Wallerian degeneration. J Neurocytol 24:667-679.

Fernandez Valle C, Gorman D, Gomez AM, Bunge MB. 1997. Actin plays a role in both changes in cell shape and gene-expression associated with Schwann cell myelination. J Neurosci 17:241-250.

Franceschini IA, Barnett SC. 1996. Low-affinity NGF-receptor and E-N-CAM expression define two types of olfactory nerve ensheathing cells that share a common lineage. Dev Biol 173:327-343.

Fu SY, Gordon T. 1997. The cellular and molecular basis of peripheral nerve regeneration. Mol Neurobiol 14:67-116.

Funakoshi H, Frisen J, Barbany G, Timmusk T, Zachrisson O, Verge VMK, Persson H. 1993. Differential expression of mRNAs for neurotrophins and their receptors after axotomy of the sciatic nerve. J Cell Biol 123:455-465.

Goda S, Hammer J, Kobiler D, Quarles RH. 1991. Expression of the myelin-associated glycoprotein in cultures of immortalized Schwann cells. J Neurochem 56:1354-1361.

Hammarberg H, Piehl F, Cullheim S, Fjell J, Hökfelt T, Fried K. 1996. GDNF mRNA in Schwann cells and DRG satellite cells after chronic sciatic nerve injury. NeuroReport 7:857-860.

Hammarberg H, Risling M, Hökfelt T, Cullheim S, Piehl F. 1998. Expression of insulin-like growth factors and corresponding binding proteins (IGFBP 1-6) in rat spinal cord and peripheral nerve after axonal injuries. J Comp Neurol 400:57-72.

Hansen MR, Vijapurkar U, Koland JG, Green SH. 2001. Reciprocal signaling between spiral ganglion neurons and Schwann cells involves neuregulin and neurotrophins. Hear Res 161:87-98.

Henderson CE, Phillips HS, Pollock RA, Davies AM, Le- 
meulle C, Armanini M, Simpson LC, Moffet B, Vandlen RA, Koliatsos VE, et al. 1994. GDNF: a potent survival factor for motoneurons present in peripheral nerve and muscle. Science 266:1062-1064.

Hijazi MM, Thompson EW, Tang C, Coopman P, Torri JA, Yang D, Mueller SC, Lupu R. 2000. Heregulin regulates the actin cytoskeleton and promotes invasive properties in breast cancer cell lines. Int J Oncology 17:629-641.

Ho WH, Armanini, MP, Nuijens A, Phillips HS, Osheroff PL. 1995. Sensory and motor neuron-derived factor, a novel heregulin variant highly expressed in sensory and motor neurons. J Biol Chem 270:14523-14532.

Höke A, Gordon T, Zochodne DW, Sulaiman OAR. 2002. A decline in glial cell-line-derived neurotrophic factor expression is associated with impaired regeneration after long-term Schwann cell denervation. Exp Neurol 173: 77-85.

Höke A, Ho T, Crawford TO, Lebel C, Hilt D, Griffin JW. 2003. Glial cell line derived neurotrophique factor alters axon Schwann cell unit and promotes myelination in unmyelinated fibers. J Neurosci 23:561-567.

Jessen KR, Brennan A, Morgan L, Mirsky R, Kent A, Hashimoto Y, Gavrilovic J. 1994. The Schwann cell precursor and its fate: a study of cell death and differentiation during gliogenesis in rat embryonic nerves. Neuron 12:509-527.

Jessen KR, Mirsky R. 1991. Schwann cell precursors and their development. Glia 4:185-194.

Jessen KR, Mirsky R. 1999. Schwann cell and their precursors emerge as major regulators of nerve development. Trends Neurosci 22:402-410.

Jessen KR, Morgan L, Mirsky R. 1987. Myelinated, but not unmyelinated reversibly down-regulate N-CAM in Schwann cells. J Neurocytol 16:681-688.

Jessen KR, Morgan L, Stewart HJS, Mirsky R. 1990. Three markers of adult non-myelin-forming Schwann cells, 217c (Ran-1) A5E3 and GFAP: development and regulation by neuron-Schwann cell interactions. Development 109:91-103

Kim SU, Yong VW, Watabe K, Shin DH. 1989. Human fetal Schwann cells in culture: phenotypic expression and proliferative capability. J Neurosci Res 22:50-59.

Kioussi C, Gross MK, Gruss P. 1995. Pax3: a paired domain gene as a regulateur in PNS myelination. Neuron 15:553562.

Kursula P, Lehto VP, Heape AM. 2001. The small myelinassociated glycoprotein binds tubulin and microtubules. Mol Brain Res 87:22-30.

Lemke G. 1993. The molecular genetics of myelination-an update. Glia 7:263-271.

Lemke G, Chao M. 1988. Axons regulate Schwann cell expression of the major myelin and NGF receptor genes. Development 102:499-504.

Lobsiger CS, Schweitzer B, Taylor V, Suter U. 2000. Platelet-derived growth factor-BB supports the survival of cultured rat Schwann cell precursor in synergy with neurotrophin-3. Glia 30:290-300.

Lobsiger CS, Smith PM, Buchstaller J, Schweitzer B,
Franklin RJM, Suter U, Taylor V. 2001. SpL201: a conditionally immortalized Schwann cell precursor line that generates myelin. Glia 36:31-47.

Love FM, Thompson WJ. 1998. Schwann cells proliferate at rat neuromuscular junction during development and regeneration. J Neurosci 18:9376-9385.

Marchionni MA, Goodearl ADJ, Chen MS, BerminghamMcDonogh O, Kirk C, Hendricks M, Danehy F, Misumi D, Sudhalter J, Kobayashi K, et al. 1993. Glial growth factors are alternatively spliced erbB2 ligands expressed in the nervous system. Nature 362:312-318.

Martini R. 2001. The effect of myelinating Schwann cells on axons. Muscle Nerve 24:456-466.

Mata M, Alessi D, Fink DJ. 1990. S100 is preferentially distributed in myelin-forming Schwann cells. J Neurocytol 19:432-442.

Meier C, Parmentier E, Brennan A, Mirsky R, Jessen KR. 1999. Developing Schwann cells acquire the ability to survive without axons by establishing an autocrine circuit involving IGF, NT-3 and PDGF-BB. J Neurosci 19: 3847-3859.

Mirsky R, Jessen KR. 1996. Schwann cell development, differentiation and myelination. Curr Opin Neurobiol 6:89-96.

Mokuno K, Kamholtz J, Behrman T, Black C, Sessa M, Feinstein D, Lee V, Pleasure D. 1989. Neuronal modulation of Schwann cell glial fibrillary acidic protein (GFAP). J Neurosci Res 23:396-405.

Pixley SK. 1992. The olfactory nerve contains two populations of glia, identified both in vivo and in vitro. Glia 5:269-284

Podratz JL, Rodriguez E, Windebank AJ. 2001. Role of the extracellular matrix in myelination of peripheral nerve. Glia 35:35-40.

Porter S, Clark MB, Glaser L, Bunge RP. 1986. Schwann cells stimulated to proliferate in the absence of neurons retain full functional capability. J Neurosci 6:3070-3078.

Raabe TD, Clive DR, Neuberger TJ, Wen D, De Vries GH. 1996. Cultured neonatal Schwann cells contains and secrete neuregulins. J Neurosci Res 46:263-270.

Rosenbaum C, Karyala S, Marchionni MA, Kim HA, Krasnoselsky AL, Happel B, Isaacs I, Brackenburry R, Ratner N. 1997. Schwann cells express NDF and SMDF/nARIA mRNAs, secrete neuregulin and show constitutive activation of erbB3 receptors: evidence for a neuregulin autocrine loop. Exp Neurol 148:604-615.

Rouleau GA, Merel P, Lutchman M, Sanson M, Zucman J, Marineau C, Hoang-Xuan K, Demczuk S, Desmaze C, Plougastel B, et al. 1993. alteration in a new gene encoding a putative membrane-organizing protein causes neuro-fibromatosis type 2. Nature 363:515-521.

Sans A, Bartolami S, Fraysse B. 1996. Histopathology of the peripheral vestibular system in small vestibular schwannomas. Am J Otology 17:326-334.

Shah NM, Marchionni MA, Issac I, Stroobant P, Anderson DJ. 1994. Glial growth factor restricts mammalian neural crest stem cells to glial fate. Cell 77:349-360. 
Sherman LS, Gutmann DH. 2001. Merlin: hanging tumor suppression on the Rac. Trends Cell Biol 11:442-444.

Son YJ, Trachtenberg JT, Thompson WJ. 1996. Schwann cells induce and guide spouting and reinnervation of neuromuscular junctions. Trends Neurosci 19:280-285.

Stewart HJS, Morgan L, Jessen KR, Mirsky R. 1993. Changes in DNA synthesis rate in the Schwann cell lineage in vivo are correlated with the precursor-Schwann cell transition and myelination. Eur J Neurosci 5:11361144.

Svenningsen AF, Kanje M. 1996. Insulin and the insulinlike growth factors I and II are mitogenic to cultured rat sciatic nerve segments and stimulate $\left[{ }^{3} \mathrm{H}\right]$ thymidine incorporation through their respective receptors. Glia 18: 68-72.

Syroid DE, Zorick TS, Arbet-Engels C, Kilpatrick TJ, Eckhart W, Lemke G. 1999. A role for insulin-like growth factor-1 in the regulation of Schwann cell survival. J Neurosci 19:2059-2068.

Tohyama K, Ide C. 1984. The localization of laminin and fibronectin on the Schwann cell basal lamina. Arch Histol Jap 47:519-532.

Topilko P, Levi G, Merlo G, Mantero S, Desmarquet C, Mancardi G, Charnay P. 1997. Differential regulation of the zinc finger genes Krox-20 and Krox-24 (Egr-1) suggests antagonistic roles in Schwann cells. J Neurosci Res 50:702-712.

Trachtenberg JT, Thompson WJ. 1996. Schwann cell apoptosis at developing neuromuscular junction is regulated by glial growth factor. Nature 379:174-177.

Trofatter JA, MacCollin MM, Rutter JL, Murrell JR, Duyao MP, Parry DM, Eldridge R, Kley N, Menon AG, Pulaski K, et al. 1993. A novel moesin-, ezrin-, radixin-like gene is a candidate for the neurofibromatosis 2 tumor suppressor. Cell 72:791-800.

Tsiper MV, Yurchenco PD. 2002. Laminin assembles into separate basement membrane and fibrillar matrices in Schwann cells. J Cell Sci 115:1005-1015.

Verdi JM, Groves AK, Farinas I, Jones K, Marchionni MA, Reichardt LF, Anderson DJ. 1996. A reciprocal cell-cell interaction mediated by NT-3 and neuregulin controls the early survival and development of sympathetic neuroblasts. Neuron 16:515-527.

Vincent AJ, West AK, Chuah MI. 2003. Morphological plasticity of olfactory ensheathing cells is regulated by cAMP and endothelin-1. Glia 41:393-403.

Watabe K, Fukuda T, Tanaka J, Honda H, Toyohara K, Sakai O. 1995. Spontaneously immortalized adult mouse Schwann cells secrete autocrine and paracrine growthpromoting activities. J Neurosci Res 41:279-290.

Weiner JA, Fukushima N, Contos JJA, Scherer SS, Chun J. 2001. Regulation of Schwann cell morphology and adhesion by receptor-mediated lysophosphatidic acid signaling. J Neurosci 21:7069-7078.

Wood PM, Schachner M, Bunge RP. 1990. Inhibition of Schwann cell myelination in vitro by antibody to the L1 adhesion molecule. J Neurosci 10:3635-3645.

Yin X, Crawford TO, Griffin JW, Tu PH, Lee VMY, Li C, Roder J, Trapp BD. 1998. Myelin-associated glycoprotein is a myelin signal that modulates the caliber of myelinated axons. J Neurosci 18:1953-1962.

Zanazzi G, Einheber S, Westreich R, Hannocks MJ, BedellHogan D, Marchionni MA, Salzer J. 2001. Glial growth factor/neuregulin inhibits Schwann cell myelination and induces demyelination. J Cell Biol 152:1289-1299.

Zorick TS, Lemke G. 1996. Schwann cell differentiation. Curr Opin Cell Biol 8:870-876. 